\title{
Harmonization of Cross-National Studies of Aging to the Health and Retirement Study
}

\author{
USER GUIDE, Health Behavior, Version A
}

Serena Wang, Joohong Min, Jinkook Lee

RAND Labor \& Population

WR-861/8

December 2014

This paper series made possible by the NIA funded RAND Center for the Study of Aging (P3OAG012815) and the NICHD funded RAND Population Research Center (R24HD050906).

RAND working papers are intended to share researchers' latest findings and to solicit informal peer review. They have been approved for circulation by RAND Labor and Population but have not been formally edited or peer reviewed. Unless otherwise indicated, working papers can be quoted and cited without permission of the author, provided the source is clearly referred to as a working paper. RAND's publications do not necessarily reflect the opinions of its research clients and sponsors. RAND $B$ is a registered trademark. 


\section{HARMONIZATION OF CROSS-NATIONAL STUDIES OF AGING TO THE HEALTH AND RETIREMENT STUDY}

USER GUIDE

Health Behavior

Version A

Serena Wang

Joohong Min

Jinkook Lee

December 2014

This project is funded by NIA/NIH (R24 AG037866) 
Table of Contents

INTRODUCTION ............................................................................................................................6

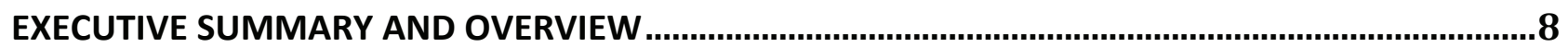

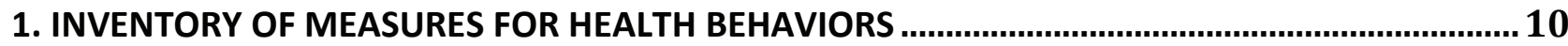

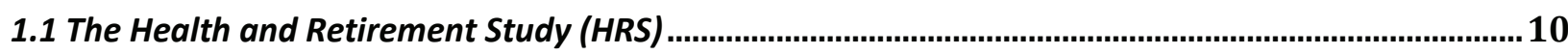

1.2 The English Longitudinal Study of Ageing (ELSA).......................................................................... 11

1.3 The Survey of Health, Ageing, and Retirement in Europe (SHARE).................................................12

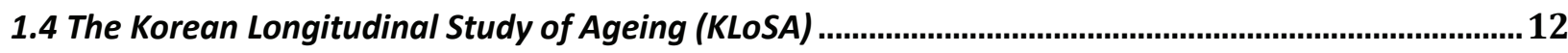

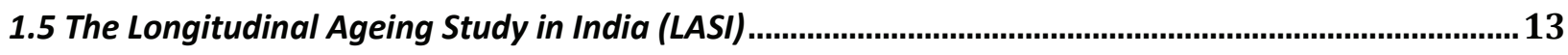

1.6 The Chinese Health and Retirement Longitudinal Study (CHARLS),............................................13

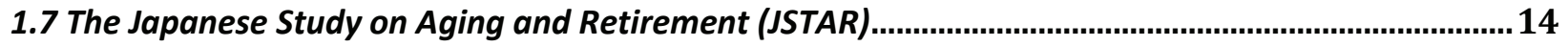

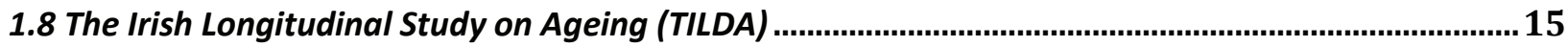

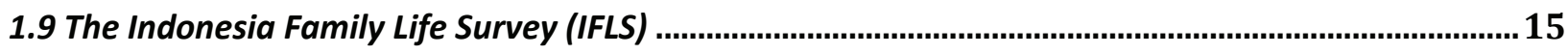

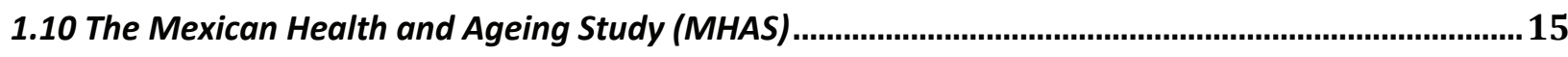

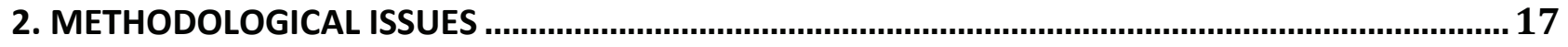

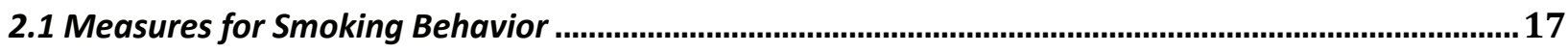

2.1.1 Ever Smoke....................................................................................................................................... 17

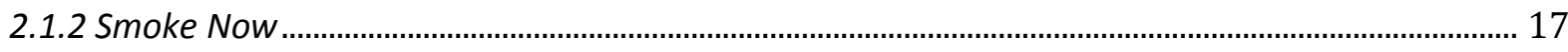

2.1.3 Quantity of Currently Smoked ................................................................................................. 17

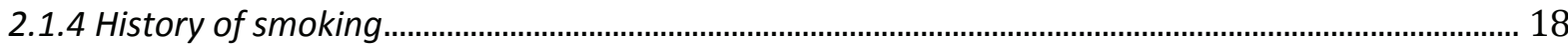

2.1.5 Quantity when smoked the most ............................................................................................. 18

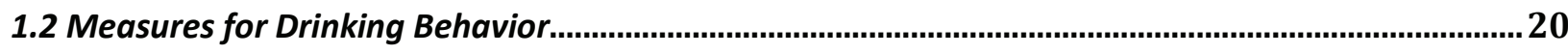

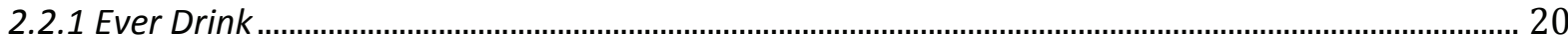

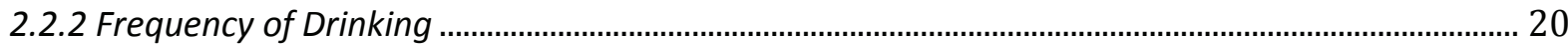

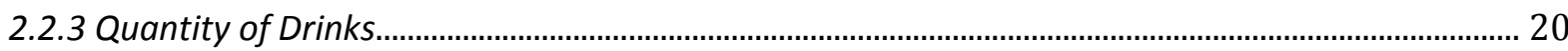

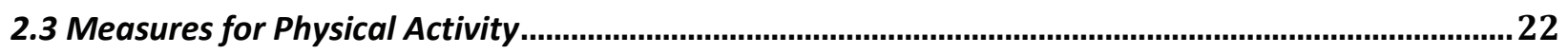

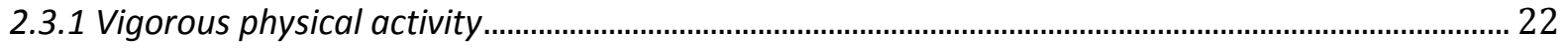

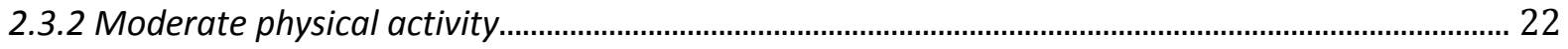

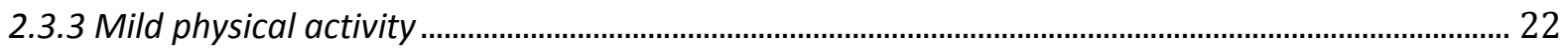

3. USING MEASURES CROSS-COUNTRY ANALYSIS ............................................................... 24 


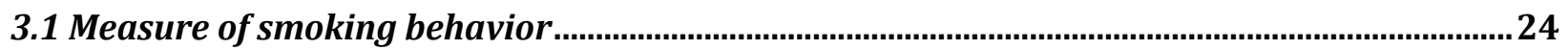

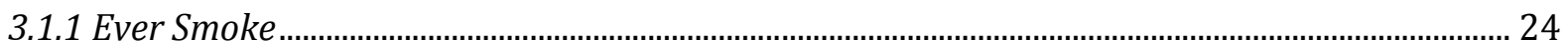

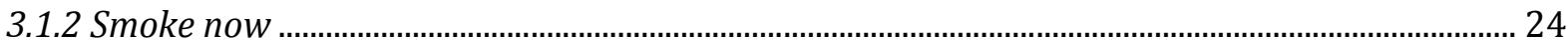

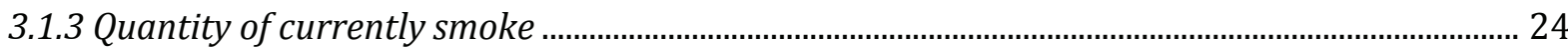

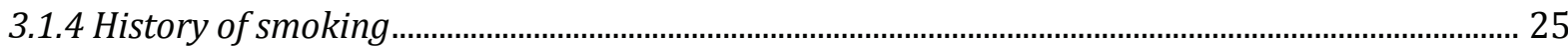

3.1.5 Quantity when smoked the most .................................................................................................. 25

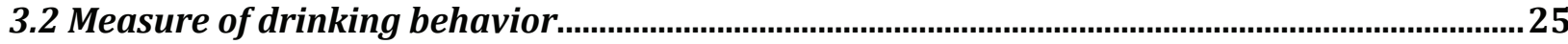

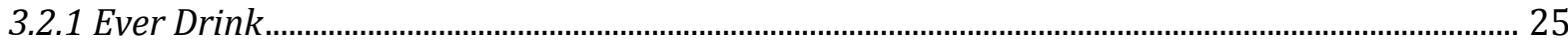

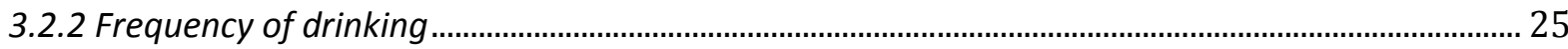

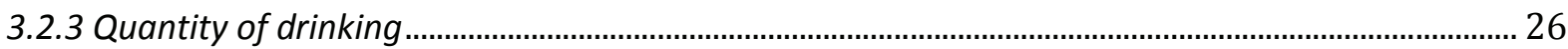

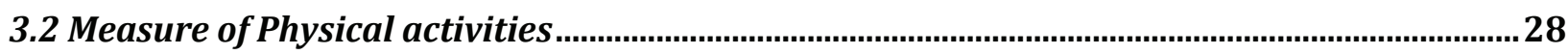

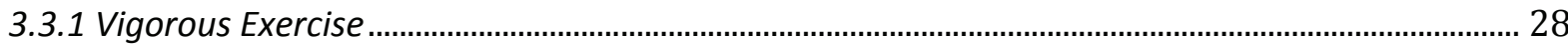

3.3.2 Moderate Exercise ........................................................................................................................... 28

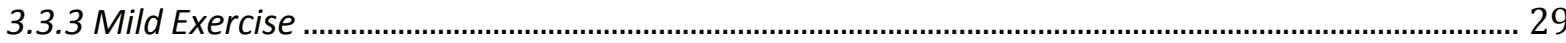

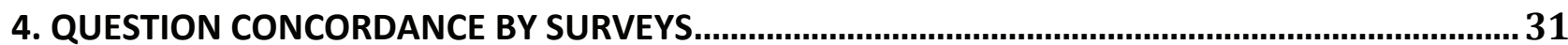

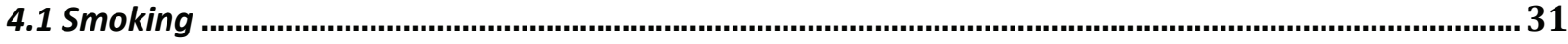

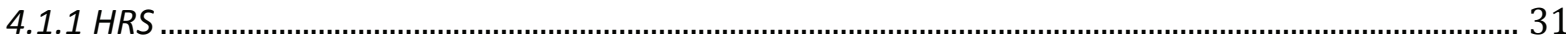

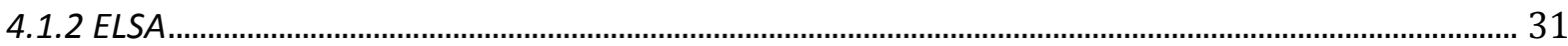

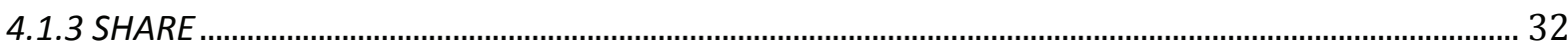

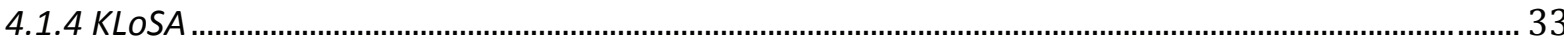

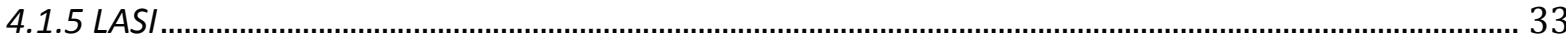

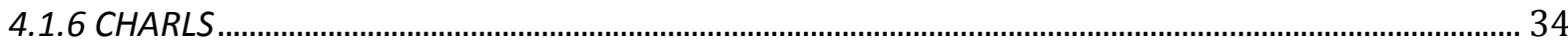

4.1.7 JSTAR

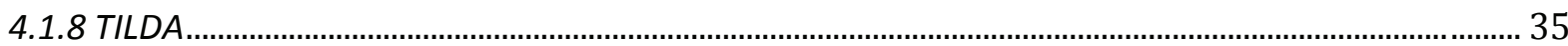

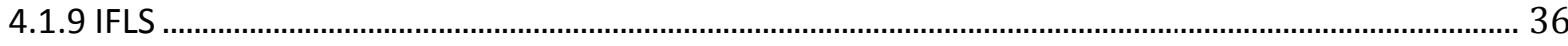

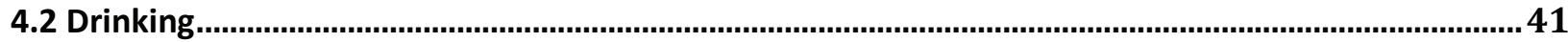

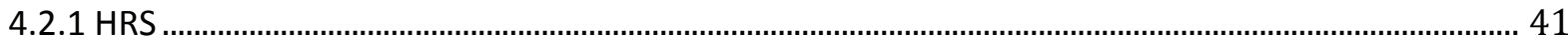

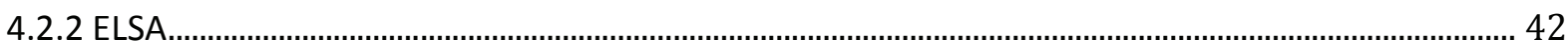

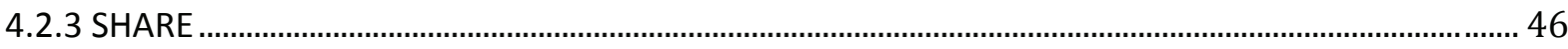

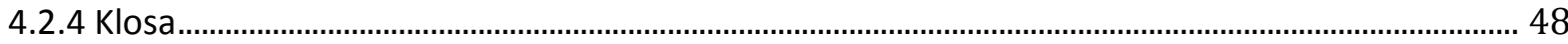

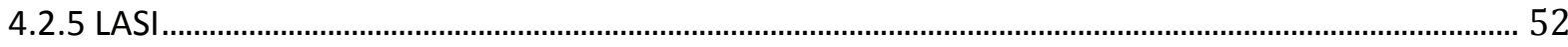

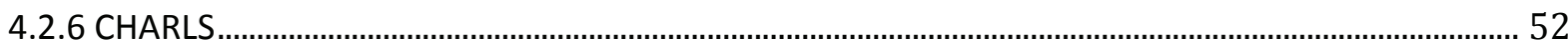

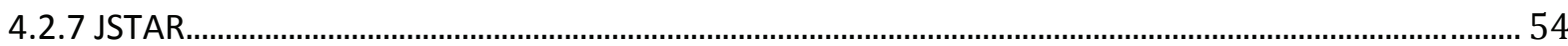


4.2.8 TILDA

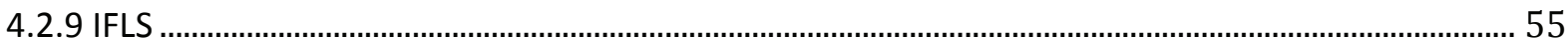

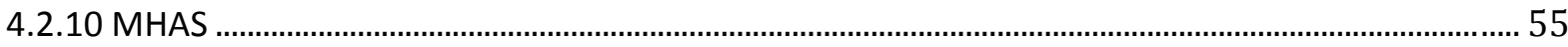

4.3 Physical activity

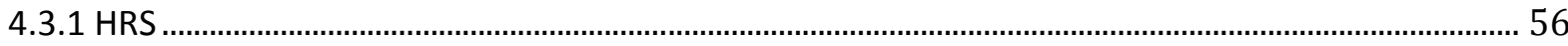

4.3.2 ELSA

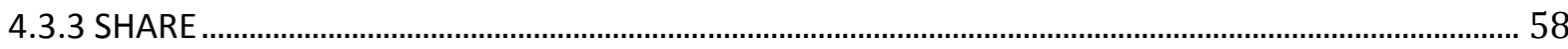

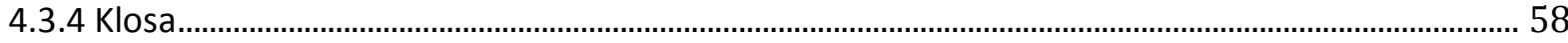

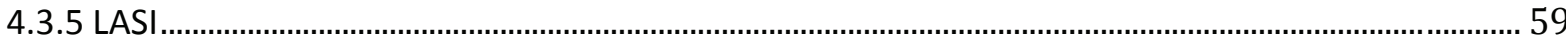

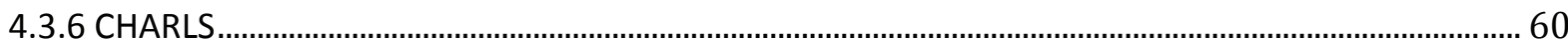

4.3.7 JSTAR

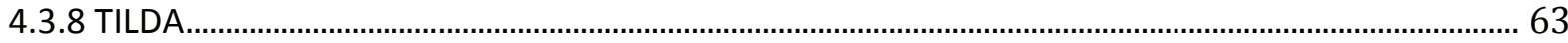

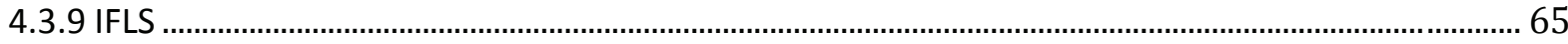

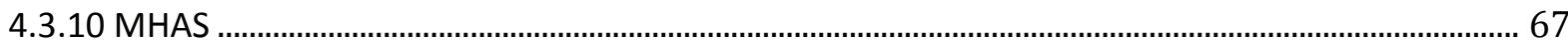




\section{LIST OF TABLES}

Table 1. Summary of Smoking Behavior Variables in Each Survey ........................................................... 19

Table 2. Summary of Drinking Variables in Each Survey ......................................................................... 21

Table 3. Summary of Physical Exercise Variables in Each Survey ….......................................................... 23

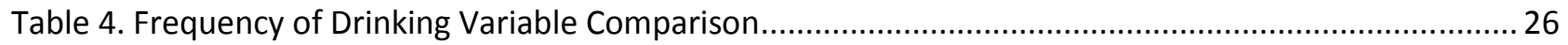

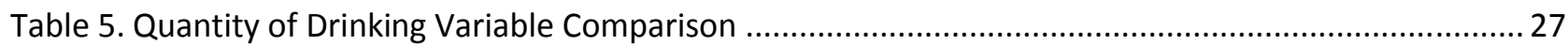

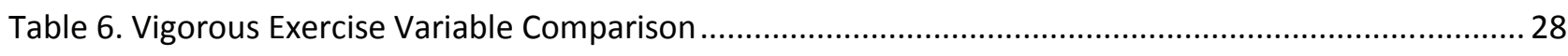

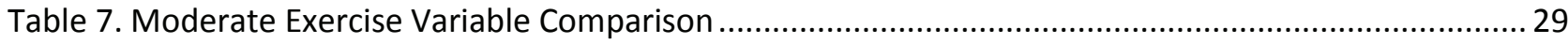

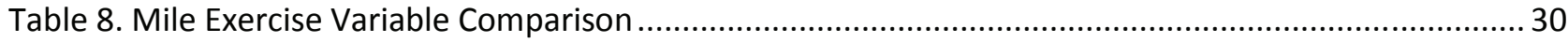

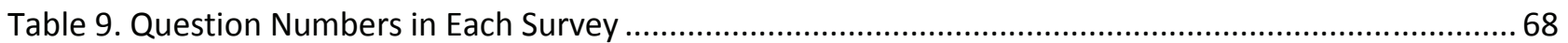




\section{INTRODUCTION}

The Health and Retirement Study (HRS) has achieved remarkable scientific success, as demonstrated by an impressive number of users and research studies and publications. Its success has generated substantial interest in collecting similar data as population aging increases around the world. The result has been a number of surveys designed to be comparable with the HRS: the English Longitudinal Study of Ageing (ELSA), the Survey of Health, Ageing, and Retirement in Europe (SHARE), the Korean Longitudinal Study of Aging (KLOSA), the Longitudinal Aging Study in India (LASI), the China Health and Retirement Longitudinal Study (CHARLS), the Japanese Study on Aging and Retirement (JSTAR), The Irish Longitudinal Study on Ageing (TILDA), the Indonesia Family Life Survey (IFLS), and the Mexican Health and Ageing Study (MHAS).. ${ }^{1}$

As these surveys have harmonization as a goal, they provide remarkable opportunities for crosscountry studies. The value of comparative analyses, especially regarding lessons resulting from policies adopted elsewhere, is widely recognized. Yet there are only a limited number of empirical studies exploiting such opportunities. This is partly due to the difficulties associated with learning multiple surveys and the policies and institutions of each country.

Identifying comparable questions across surveys is the first step toward cross-country analyses. The USC CENTER FOR GLOBAL AGING RESEARCH web site (https://g2aging.org/) provides users a digital library of questions for all these surveys. Its search engines enable users to examine cross-country concordance for each survey question. Using them, researchers can identify all questions related to particular key words or within a domain or a sub- domain.

Nevertheless, comparing these questions and evaluating comparability across surveys is still a labor-intensive process. Understanding all the idiosyncratic details in each survey takes still more effort. To reduce time and effort needed for cross-country research, we have prepared a series of domain-specific user guides. These guides are designed to provide researchers with documentation about the concepts, measures, and questions of particular domains in all HRS-family surveys. For each domain, we reviewed all relevant questions across all surveys. These guides expand upon the information found in codebooks, questionnaires, and data descriptions. They also evaluate comparability across surveys and recommendations for harmonized measures that can be exploited for

\footnotetext{
${ }^{1}$ For an overview of these studies, see Lee, J. (2010). Data set for pension and health: Data collection and sharing for policy design, International Social Security Review, 63, (3-4), 197 - 222.
} 
cross-country analyses. We hope these guides, by helping researchers save time and better understand what can be studied in HRS-family surveys, accelerate scientific advances.

This health-behavior user guide focuses on three health behaviors: smoking, drinking, and physical exercise. We chose these three specific health behaviors for this guide because they are known predictors of health risks, and all HRS family of surveys include a series of questions on them. 


\section{EXECUTIVE SUMMARY AND OVERVIEW}

This guide summarizes data on health behavior from the Health and Retirement Study (HRS) and its sister surveys. This includes the 2004, 2006, 2008, and 2010 waves of the HRS, ${ }^{2}$ the five waves of the English Longitudinal Study of Ageing (ELSA), Waves 1, 2, and 4 of the Survey of Health, Ageing, and Retirement in Europe (SHARE, whose Wave 3 is life history survey), all four waves of the Korean Longitudinal Study of Ageing (KLoSA), the Longitudinal Ageing Study in India (LASI) pilot wave, all three waves of the Japanese Study on Aging and Retirement (JSTAR), the first waves of the China Health and Retirement Longitudinal Study (CHARLS) and the Irish Longitudinal Study on Ageing (TILDA), the 2007 wave of the Indonesia Family Life Survey (IFLS), and the first two waves of the Mexican Health and Ageing Study (MHAS). All of the surveys collected information on common health behaviors, but varied in the spectrum and details of questions asked. We group the health behavior measures into three: smoking behavior, drinking behavior, and physical activity.

\section{Smoking behavior}

- All surveys ask whether the respondent ever smoked but differed in time span. Most surveys asked respondents if they had ever smoked in their lifetime, providing comparability. KLoSA asks respondents if they have ever smoked more than five packs of cigarettes (100 cigarettes), meaning it will underestimate prevalence of lifetime smoking relative to their surveys asking if respondents have ever smoked.

- The surveys differ in type of tobacco products included. HRS, KLoSA, CHARLS, JSTAR, and MHAS only ask about cigarettes. ELSA asks about cigarettes and rollups. SHARE, TILDA, and IFLS also ask about smoking pipes, cigars, and cigarettes. LASI asks about cigarette, bidi, cigar, hookah, chewing tobacco, gutka, and pan masala.

- All the surveys except ELSA ask respondents how much they currently smoke each day. Again, however, the surveys differ in the types of tobacco products they include: HRS, KLOSA, CHARLS, JSTAR and MHAS only ask about cigarettes, while ELSA, SHARE, TILDA, and IFLS ask about other types of tobacco products. ELSA further differentiates weekend and weekday smoking.

- All the surveys except ELSA ask several questions about personal smoking history. These include age or year when or number of years since respondents started smoking as well as the age or year when or number of years since respondents stopped smoking.

\footnotetext{
${ }^{2}$ Prior to 2004, HRS provides a document summarizing all the health behavior measures across waves. The document can be found at http://hrsonline.isr.umich.edu/sitedocs/userg/dr-010.pdf
} 
- Three surveys, HRS, KLoSA, and MHAS, ask respondents the quantity of cigarettes or packs daily consumed when they most smoked.

Drinking behavior

- HRS, KLoSA, LASI, CHARLS, and MHAS ask respondents whether they "ever" drank alcohol. ELSA asks respondents whether they did so in the past year, JSTAR asks about the past six months, and SHARE asks about the past three months (and past six months in wave 1). TILDA and IFLS do not ask about any past alcohol consumption.

- All the surveys, except ELSA wave 1, LASI, IFLS, and TILDA, ask the frequency of drinking when the respondent consumed alcoholic drinks. Such questions differ in answer options for time span and type of drink.

\section{Physical activity}

- Except for KLoSA and JSTAR, the surveys ask about vigorous exercise and moderate exercise. They differ in time span and frequency of exercise reported. HRS, ELSA, SHARE and LASI are comparable in offering a measure on frequency of exercise with no specific time frame. CHARLS, TILDA, and IFLS report the number of days of exercise in the past week.

- HRS, ELSA, CHARLS, TILDA and IFLS ask about mild exercise but differ in time span and frequency measures. This measure is comparable only between HRS and ELSA. 


\section{INVENTORY OF MEASURES FOR HEALTH BEHAVIORS}

This guide provides an overview of health-behavior measures, specifically those on smoking, drinking, and physical activity, and their comparability for several surveys on aging around the world. We have prepared this guide to help researchers understand the comparability of these measures and facilitate cross-country research. The specific surveys we review are the Health and Retirement Study (HRS, 2004 Wave 7-2010 Wave 10), the English Longitudinal Study of Ageing (ELSA (2002 Wave 1-2010 Wave 5), the Survey of Health, Ageing, and Retirement in Europe (SHARE (2014 Wave 1- 2010 Wave 4) ${ }^{3}$, the Korean Longitudinal Study of Ageing (KLoSA, 2006 Wave 1 - 2012 Wave 4), the Longitudinal Ageing Study in India (LASI, pilot wave - 2010), the China Health and Retirement Longitudinal Study (CHARLS, 2010 Wave 1), the Japanese Study on Aging and Retirement (JSTAR, 2007 Wave 1 - 2011 Wave 3), the Irish Longitudinal Study on Ageing (TILDA, 2009 Wave 1), the Indonesia Family Life Survey (IFLS, 2007 Wave 4), and the Mexican Health and Ageing Study (MHAS, 2001 Wave 1- 2003 Wave 2).

In this chapter, we present an overview of the questions each survey asks on smoking behavior, drinking behavior, and physical activity. In the second chapter, we explore methodological issues regarding these, including variations in how the questions are asked. In the third chapter, we explore more directly comparability of questions across surveys and issues in using measures for cross-country analysis. The fourth chapter discusses concordance among surveys by presenting text of individual questions from each survey.

\subsection{The Health and Retirement Study (HRS)}

\subsubsection{Smoking Behavior}

The HRS asks several measures of smoking status. It includes two questions current smoking: whether smoke now and quantity smoked. It also asks several questions about smoking history, including whether ever smoke, when respondents started or stopped smoking, and the quantity of cigarettes or packs smoked at peak daily consumption. These questions have been asked of new respondents in all subsequent waves.

\subsubsection{Drinking Behavior}

HRS survey asks detailed questions on alcohol consumption. These include whether respondents ever drank, quantity of alcohol consumed, and the number of days per week consuming drinks in the last three months.

\footnotetext{
${ }^{3}$ SHARE wave 3 is the life history survey
} 


\subsubsection{Physical Activity}

The HRS asks respondents about exercise behavior in several ways. Since 2004, it has asked three questions about physical activity, including whether vigorous, moderate, or mild physical activity has occurred daily, more than once weekly, once weekly, one to three times monthly, or never. Vigorous activities include activities such as running or jogging, swimming, cycling, aerobics or gym workout, tennis, or digging with a spade or shovel. Moderate activities include gardening, cleaning the car, walking at a moderate pace, dancing, and floor or stretching exercises. Mild activities include vacuuming, laundry, and home repairs.

\subsection{The English Longitudinal Study of Ageing (ELSA)}

\subsubsection{Smoking Behavior}

ELSA asks respondents whether they have ever smoked cigarettes. This question does not distinguish other types of tobacco. Another question on current smoking status distinguishes among types of tobacco, including cigarettes and roll-up. Regarding current daily smoking, ELSA distinguishes by weekend and weekday. In other words, it asks about weekday cigarettes, weekend cigarettes, weekday roll-ups, and weekend roll-ups. It also asks quantity of roll-up tobacco consumed in grams or ounces.

\subsubsection{Drinking Behavior}

ELSA questions on drinking behavior differ by wave. Wave 1 asks only in the core survey whether the respondent has taken an alcoholic drink in the past 12 months. Starting in wave 2, the survey asks in the self-completion portion whether respondents drink any alcohol, frequency of drinking, and quantity of drinks. Specifically, waves 2 and 3 ask respondents about the day in the past week they drank most and then about consumption of pints, large cans or bottles, or small cans or bottles of normal beer; pints, or large cans or bottles of strong beer; glasses of spirits or liquor; glasses of sherry or martini; glasses of wine; and bottles or cans of alcopops. The wave 4 self-completion survey asks respondents, "During the last seven days, how many drinks did you have?" It then asks separately the number of measures of spirits, glasses of wine, and pints of beer the respondent consumed.

\subsubsection{Physical Activity}

ELSA asks respondents whether they engaged in vigorous, moderate, or mild physical activity and if doing so more than once weekly, once weekly, one to three times monthly, or hardly ever or never. 
ELSA uses a slightly different scale than used in the HRS, not allowing respondents to identify daily activity, while allowing answers of "hardly ever or never". ELSA does not ask physical activity questions of proxy respondents in waves 1 and 2 but does so for wave 3 and subsequent waves.

\subsection{The Survey of Health, Ageing, and Retirement in Europe (SHARE)}

\subsubsection{Smoking Behavior}

Unlike the HRS, the SHARE asks not only about smoking of cigarettes, also of cigars, cigarillos, and pipes daily for at least one year. In asking about quantities, SHARE asks separately about cigarettes, pipe, and cigars or cigarillos. It also asks respondents their age when starting and stopping smoking.

\subsubsection{Drinking Behavior}

SHARE questions about drinking behavior different by wave. In wave 1, the SHARE asks respondents whether they had any alcoholic drink in the last six months. In wave 2 and subsequent waves, it asks about the past three months. Regarding the frequency of drinking, the SHARE asks respondents whether they drink almost every day, five or six days weekly, three or four days weekly, once or twice weekly, once or twice monthly, less than once monthly, or not at all. It also asks respondents the number of drinks they've had on days they drank.

\subsubsection{Physical Activity}

The SHARE asks only about vigorous and moderate physical activity; it does not ask about mild physical activity question. It asks respondents whether they undertake vigorous or moderate activity more than once weekly, once weekly, one to three times monthly, or hardly ever or never.

\subsection{The Korean Longitudinal Study of Ageing (KLOSA)}

\subsubsection{Smoking Behavior}

The KLoSA asks whether respondents have ever smoked cigarettes but defines having ever smoked as having consumed more than 5 packs of cigarettes (100 cigarettes). It does not ask about other types of tobaccos in the ever-smoked question. It also asks about current daily number of cigarettes smoked. KLoSA, along with HRS and MHAS, is one of the few surveys that ask about peak lifetime tobacco consumption. It also asks respondent their age when starting or stopping smoking.

\subsubsection{Drinking Behavior}


The KLoSA asks respondents whether they have ever drunk alcohol and whether they still do so.

Frequencies it asks are none or less once monthly, once monthly, two to three times monthly, once weekly, two to three times weekly, four to five times weekly, daily, and more than twice daily. The KLoSA asks these questions separately for So-ju (Korean liquor), beer, Makgeolli (rice wine), whisky, and wine.

\subsubsection{Physical Activity}

The KLoSA asks respondents whether they worked out more than once weekly and, if so, how often. It does not ask about vigorous, moderate, or mild levels of activity.

\subsection{The Longitudinal Ageing Study in India (LASI)}

\subsubsection{Smoking Behavior}

The LASI asks several questions about smoking. It asks whether respondents have ever smoked cigarettes, bidi, cigars, or hookah, or whether they have ever chewed tobacco, gutka, or pan masala. Regarding quantities, the LASI first asks the amount of grams of tobacco consumed daily, weekly, and monthly, then the number of times tobacco was consumed daily, weekly, or monthly, and finally the number of cigarettes and the number of packs smoked in a day. It also asks respondents their age when starting or stopping smoking.

\subsubsection{Drinking Behavior}

LASI asks respondents whether they have ever drunk alcohol and whether they still do so. It asks respondents how many drinks they had in the past 30 days.

\subsubsection{Physical Activity}

The LASI asks about vigorous and moderate physical activity but does not ask about mild physical activity question. It asks whether respondents engaged in physical activity daily, more than once weekly, once week, one to three times monthly, or hardly ever or never.

\subsection{The Chinese Health and Retirement Longitudinal Study (CHARLS)}

\subsubsection{Smoking Behavior}

The CHARLS asks respondents whether they have ever smoked cigarettes (including self-rolled), cigars, or pipe tobacco, as well as whether they have ever chewed tobacco. It also asks the number of cigarette 
smoked daily now or when smoking. Finally, it asks respondents their age when they began or stopped smoking.

\subsubsection{Drinking Behavior}

The CHARLS asks respondents whether they have never had an alcoholic drink, drink less than once monthly, or drink more than once monthly. Regarding frequency of drinking, it also asks whether respondents drink less than once monthly, once monthly, two to three times monthly, once weekly, two to three times weekly, four to five times weekly, once daily, or more than twice daily. The CHARLS asks these questions separately for liquor, beer, and wine or rice wine. Regarding quantities, it asks respondents how many bottles of beer they drank or how many liang (50 cc) of wine or liquor they drank.

\subsubsection{Physical Activity}

The CHARLS asks respondents whether they engage in vigorous, moderate, or mild exercise for at least ten minutes and, if so, how many days they did so in the past week.

\subsection{The Japanese Study on Aging and Retirement (JSTAR)}

\subsubsection{Smoking Behavior}

The JSTAR asks respondents whether they smoke now, smoked in the past but have quit, or never smoked regularly. Regarding quantity of smoking, it asks the average daily number of packs of cigarettes smoked. It also asks respondents their age when they started or quit smoking.

\subsubsection{Drinking Behavior}

The JSTAR asks respondents whether they have had an alcoholic drink in the past six months, with the exception of five cities survey in wave 2. It asks respondents whether they drank daily, five to six times weekly, three to four times weekly, once or twice weekly, several times per month, or hardly ever or never. It asks respondents the number of times they drank beer, shochu, sake, whiskey, and wine.

\subsubsection{Physical Activity}

JSTAR asks respondents on self-completion questionnaires how much time they engage in exercise on weekends and weekdays. 


\subsection{The Irish Longitudinal Study on Ageing (TILDA)}

\subsubsection{Smoking Behavior}

TILDA asks respondents whether they have ever smoked cigarettes, cigars or cigarillos, or a pipe daily for a period of at least one year. It also asks respondents how many times on average they smoke or smoked each of these. Finally, it asks respondents their age when starting or stopping smoking.

\subsubsection{Drinking Behavior}

TILDA does not ask questions about drinking.

\subsubsection{Physical Activity}

TILDA asks respondents how often they engaged in vigorous, moderate, and mild exercise in the past week for at least ten minutes continuously. It also asks respondents the number of days they engaged in such activities.

\subsection{The Indonesia Family Life Survey (IFLS)}

\subsubsection{Smoking Behavior}

The IFLS asks respondents whether they have ever smoked cigarettes (including self-rolled), a pipe, and cigars, as well as whether they have ever chewed tobacco. It also asks the quantities of each type consumed. Finally, it asks respondents their age when starting or stopping smoking.

\subsubsection{Drinking Behavior}

The IFLS did not ask respondents about drinking.

\subsubsection{Physical Activity}

The IFLS asked respondents whether they engaged in vigorous, moderate, or mild exercise for at least ten minutes continuously in the past week, and, if so, on how many days they did so.

\subsection{The Mexican Health and Ageing Study (MHAS)}

\subsubsection{Smoking Behavior}

The MHAS asks respondents whether they have ever smoked cigarettes. It does not ask specifically about other types of tobacco. Regarding quantity of smoking, it asks the number of cigarettes or packs smoked daily. It also asks respondents their age when starting or quitting smoking. 


\subsubsection{Drinking Behavior}

MHAS asks respondents whether they have ever had a drink, and specifically whether they ever drink any alcoholic beverages such as beer, wine, liquor, or pulque. It also asks respondents their weekly frequency of drinking the past three months, and the number of days they had four or more drinks on one occasion.

\subsubsection{Physical Activity}

MHAS asks respondents whether, on average, they have exercised or done hard physical work at least three times weekly. It does not ask about other types of physical activity. 


\section{METHODOLOGICAL ISSUES}

As the previous section showed, each survey asks many similar questions about smoking, drinking, and physical activity, but these questions often have subtle or significant differences. In this section, we summarize methodological similarities and differences in available health-behavior questions across various surveys. Although all the surveys collected information on common health behaviors, their questions and answer categories vary by survey. We summarize below differences and similarities among surveys regarding smoking behavior, drinking behavior, and physical activity.

\subsection{Measures for Smoking Behavior}

\subsubsection{Ever Smoke}

All surveys ask whether respondents ever smoked, but differ in questions on time span and type of tobacco products. Table 1 summarizes these differences. Most surveys ask respondents whether they have ever smoked. The SHARE and the TILDA qualify this by asking respondents whether they ever smoked daily for at least one year, while the KLoSA does so by asking whether the respondent has ever consumed five packs of cigarettes. HRS, ELSA, MHAS and KLOSA do not ask specifically about tobacco consumption other than cigarettes. JSTAR asks about tobacco in general without specifying type of tobacco products. The SHARE, CHARLS and IFLS ask about cigars, cigarillos or pipes, while the LASI asks about cigarettes, bidis, cigars, hookahs, chewing tobacco, gutka, and pan masala.

\subsubsection{Smoke Now}

All surveys ask whether the respondent is currently smoking, typically requiring a simple yes or no answer. The LASI asks respondents whether they chew or sniff, smoke, or quit tobacco. JSTAR asks respondents whether they smoke now, smoked in the past but quit, or never smoked regularly.

\subsubsection{Quantity of Currently Smoked}

All surveys ask quantity of current tobacco consumption, with some variations. Most surveys ask about daily consumption, but the ELSA differentiates between weekends and weekdays. The LASI also allows respondents to specify daily, weekly, or monthly consumption. The surveys also differ in questions regarding types of tobacco consumption. The HRS, KLoSA, CHARLS, JSTAR, and MHAS only ask about cigarettes. The ELSA asks about cigarette and rollup consumption. The SHARE, TILDA, and IFLS ask about pipe tobacco, cigar, and cigarette consumption. The LASI asks about cigarette, bidi, cigar, hookah, chewing tobacco, gutka, and pan masala consumption. 


\subsubsection{History of smoking}

All the surveys except the ELSA ask about smoking history, including the age, year when or number of years since respondents started or stopped smoking.

\subsubsection{Quantity when smoked the most}

HRS, KLoSA, and MHAS ask the quantity of cigarettes or packs smoked at the peak of consumption. 
Table 1. Summary of Smoking Behavior Variables in Each Survey

\begin{tabular}{|c|c|c|c|c|c|c|c|c|c|c|}
\hline & HRS & ELSA & SHARE & KLoSA & LASI & CHARLS & JSTAR & TILDA & IFLS & MHAS \\
\hline \begin{tabular}{|l} 
Ever \\
smoke: \\
Time Span
\end{tabular} & Ever & Ever & $\begin{array}{l}\text { Daily for a } \\
\text { period of at } \\
\text { least one year }\end{array}$ & Ever & Ever & Ever & Ever regularly & $\begin{array}{l}\text { Daily for a } \\
\text { period of at } \\
\text { least one } \\
\text { year }\end{array}$ & Ever & Ever \\
\hline $\begin{array}{l}\text { Ever } \\
\text { smoke: } \\
\text { Type }\end{array}$ & \begin{tabular}{|l|} 
Cigarettes. \\
Do not \\
include \\
pipes or \\
cigars
\end{tabular} & $\begin{array}{l}\text { Cigarettes. } \\
\text { Do not } \\
\text { include } \\
\text { pipes or } \\
\text { cigars }\end{array}$ & $\begin{array}{l}\text { Cigarettes, } \\
\text { cigars, } \\
\text { cigarillos or a } \\
\text { pipe }\end{array}$ & $\begin{array}{l}\text { More than } \\
5 \text { packs of } \\
\text { cigarettes } \\
(100 \\
\text { cigarettes })\end{array}$ & $\begin{array}{l}\text { Cigarette, bidi, } \\
\text { cigar, hookah, or } \\
\text { chewing tobacco, } \\
\text { gutka, pan } \\
\text { masala }\end{array}$ & $\begin{array}{l}\text { Chewed } \\
\text { tobacco, } \\
\text { pipe, self- } \\
\text { rolled } \\
\text { cigarettes, } \\
\text { cigars }\end{array}$ & Any tobacco & $\begin{array}{l}\text { cigarettes, } \\
\text { cigars, } \\
\text { cigarillos or } \\
\text { a pipe }\end{array}$ & $\begin{array}{l}\text { Chewed } \\
\text { tobacco, pipe, } \\
\text { self-rolled } \\
\text { cigarettes, } \\
\text { cigars }\end{array}$ & $\begin{array}{l}\text { Cigarettes. Do } \\
\text { not include } \\
\text { pipes or cigars }\end{array}$ \\
\hline $\begin{array}{l}\text { Smoke } \\
\text { now }\end{array}$ & Yes/No & Yes/No & Yes/No & Yes/No & $\begin{array}{l}\text { 1. Yes, I chew or } \\
\text { sniff tobacco; } \\
\text { 2. Yes, I smoke } \\
\text { tobacco; } \\
\text { 3. No, I quit }\end{array}$ & Yes/no & $\begin{array}{l}\text { 1. Yes, I smoke } \\
\text { now; } \\
\text { 2. I smoke in } \\
\text { the past, quit } \\
\text { now; } \\
\text { 3.No, I never } \\
\text { smoked } \\
\text { regularly }\end{array}$ & Yes/No & Yes/No & Yes/No \\
\hline $\begin{array}{l}\text { Quantity- } \\
\text { Time Span }\end{array}$ & In a day & $\begin{array}{l}\text { Weekend or } \\
\text { weekday }\end{array}$ & In a day & In a day & $\begin{array}{l}\text { Given: } \\
\text { day/week/month }\end{array}$ & In a day & In a day & In a day & In a day & In a day \\
\hline $\begin{array}{l}\text { Quantity- } \\
\text { type }\end{array}$ & $\begin{array}{l}\text { Cigarettes } \\
\text { or packs }\end{array}$ & $\begin{array}{l}1 . \\
\text { Cigarettes; } \\
\text { 2. Roll-up }\end{array}$ & $\begin{array}{l}\text { 1.Cigarettes; } \\
\text { 2.Pipe; } \\
\text { 3.Cigars or } \\
\text { cigarillos }\end{array}$ & $\begin{array}{l}\text { Cigarettes } \\
\text { or packs }\end{array}$ & $\begin{array}{l}\text { 1.Tabacco } \\
\text { [Cigarette, bidi, } \\
\text { cigar, hookah]; } \\
\text { 2.smokeless } \\
\text { tobacco [ } \\
\text { chewing tobacco, } \\
\text { gutka, pan } \\
\text { masala] }\end{array}$ & Cigarettes & $\begin{array}{l}\text { Cigarettes or } \\
\text { packs }\end{array}$ & $\begin{array}{l}\text { 1.Cigarettes; } \\
\text { 2.Pipe; } \\
\text { 3.Cigars or } \\
\text { cigarillos }\end{array}$ & $\begin{array}{l}\text { 1.Chewing } \\
\text { tobacco; } \\
\text { 2.pipe; } \\
\text { 3.Self-rooled } \\
\text { cigarettes;4.Ciga } \\
\text { rettes/cigars }\end{array}$ & $\begin{array}{l}\text { Cigarettes or } \\
\text { packs }\end{array}$ \\
\hline $\begin{array}{l}\text { History of } \\
\text { smoking }\end{array}$ & \begin{tabular}{|l|} 
1.Age/year \\
start, \\
2.Age/year \\
stop, \\
3. \# years \\
\end{tabular} & NA & $\begin{array}{l}\text { 1.Age stop } \\
\text { 2. \# years }\end{array}$ & $\begin{array}{l}\text { 1.Age, } \\
\text { 2.Year start, } \\
\text { 3.Age, year } \\
\text { stop }\end{array}$ & $\begin{array}{l}\text { 1.Age start, } \\
\text { 2.Age stop }\end{array}$ & $\begin{array}{l}\text { 1.Age start } \\
\text { 2.Age stop }\end{array}$ & $\begin{array}{l}\text { 1.Age start, } \\
\text { 2.Age stop }\end{array}$ & $\begin{array}{l}\text { 1.Age stop, } \\
\text { 2. \# years }\end{array}$ & $\begin{array}{l}\text { 1.Age start, } \\
\text { 2.Age stop }\end{array}$ & Age start \\
\hline $\begin{array}{l}\text { Smoke the } \\
\text { most }\end{array}$ & $\begin{array}{l}\text { Cigarettes } \\
\text { or packs }\end{array}$ & NA & NA & $\begin{array}{l}\text { Cigarettes } \\
\text { or packs }\end{array}$ & NA & NA & NA & NA & NA & $\begin{array}{l}\text { Cigarettes or } \\
\text { packs }\end{array}$ \\
\hline
\end{tabular}




\subsection{Measures for Drinking Behavior}

\subsubsection{Ever Drink}

All the surveys except TILDA and IFLS ask respondents whether they have drunk alcohol but differ in time spans they consider. Many consider lifetime consumption. JSTAR asks about consumption in the past six months and in wave 2 only of two cities. The ELSA asks respondents whether they drank in the past 12 months. SHARE wave 1 asks about consumption in the past six months, while SHARE waves 2 and 4 ask about the past three months. Table 2 summarizes the differences.

\subsubsection{Frequency of Drinking}

Except for TILDA, LASI, IFLS, and ELSA wave 1, all studies ask the frequency of drinking when the respondent consumed alcoholic drinks. They differ in three ways: time span, option of answers, and type of drinks considered. The HRS, SHARE waves 2 and 4, and MHAS ask about consumption in the last three months while ELSA waves 2, 3, and 4 asks about consumption in the past seven days. SHARE wave 1 and JSTAR use the time span of 6 months. The KLOSA and CHARLS use the time span of last year. The HRS, ELSA waves 2, 3, and 4, and MHAS ask the number of weekly days of consumption. SHARE, KLoSA, CHARLS, and JSTAR offer varying category answers on frequencies. Most surveys ask about any alcoholic beverages consumed, but KLoSA and CHARLS ask about specific drink types.

\subsubsection{Quantity of Drinks}

Except for TILDA, ELSA wave 1, SHARE wave 1, and IFLS, each survey asks number of drinks consumed daily. Again, however, there are differences in time span and type of drinks considered. For time span, HRS, SHARE waves 2 and 4, and MHAS refer to the last three months. ELSA refers to the last seven days, but in waves 2 and 3 asks about the day of greatest alcohol consumption. ELSA wave 3 asks number of drinks during last seven days. KLoSA and CHARLS refer to last year. LASI refers to the last 30 days. The HRS, SHARE waves 2 and 4, LASI, and MHAS do not specify types of drinks, but ELSA waves 2, 3, and 4, KLOSA, CHARLS, and JSTAR do. 
Table 2. Summary of Drinking Variables in Each Survey

\begin{tabular}{|c|c|c|c|c|c|c|c|c|c|c|c|c|c|c|}
\hline & \multirow[b]{2}{*}{ HRS } & \multicolumn{3}{|c|}{ ELSA } & \multicolumn{2}{|c|}{ SHARE } & \multirow[b]{2}{*}{ KLoSA } & \multirow[b]{2}{*}{ LASI } & \multirow[b]{2}{*}{ CHARLS } & \multicolumn{2}{|l|}{ JSTAR } & \multirow[b]{2}{*}{ STILDA } & \multirow[b]{2}{*}{ IFLS } & \multirow[b]{2}{*}{ MHAS } \\
\hline & & W1 & W2, W3 & W4, W5 & W1 & W3, W4 & & & & $\begin{array}{l}\mathrm{w} 1, \mathrm{w} 2(2 \\
\text { cities),w3 }\end{array}$ & $\begin{array}{l}w 2 \\
5 \text { cities }\end{array}$ & & & \\
\hline $\begin{array}{l}\text { Ever drink: } \\
\text { time span }\end{array}$ & Ever & $\begin{array}{l}\text { Last } 12 \\
\text { months }\end{array}$ & Same w1 & Same w1 & Last 6 months & Last 3 months & Ever & Ever & Ever & Last 6 months & NA & NA & NA & Ever \\
\hline $\begin{array}{l}\text { Frequency } \\
\text { : time } \\
\text { span }\end{array}$ & $\begin{array}{l}\text { Last } 3 \\
\text { months }\end{array}$ & NA & Last 7 days & $\begin{array}{l}\text { Last } 7 \\
\text { days }\end{array}$ & Last 6 months & Last 3 months & $\begin{array}{l}\text { Last year: month } \\
\text { or week }\end{array}$ & NA & $\begin{array}{l}\text { Last year: month } \\
\text { or week }\end{array}$ & Last 6 months & NA & NA & NA & $\begin{array}{l}\text { Last } 3 \\
\text { month }\end{array}$ \\
\hline $\begin{array}{l}\text { Frequency } \\
\text { answer }\end{array}$ & $\begin{array}{l}\text { \# days } \\
\text { per } \\
\text { week }\end{array}$ & NA & $\begin{array}{l}\text { \# days per } \\
\text { week }\end{array}$ & \# days per & $\begin{array}{l}1 \text { Almost every } \\
\text { day; } \\
\text { 2.Five or six days a } \\
\text { week; } \\
\text { 3.Three or four } \\
\text { days; } \\
\text { 4. Once or twice a } \\
\text { week; } \\
\text { 5. Once or twice a } \\
\text { month; } \\
6 . \text { Less than once a } \\
\text { month; } \\
\text { 7.Not at all in last } \\
6 \text { months } \\
\end{array}$ & $\begin{array}{l}1 \text { Almost every } \\
\text { day, } \\
\text { 2.Five or six days a } \\
\text { week; } \\
\text { 3.Three or four } \\
\text { days; } \\
\text { 4.Once or twice a } \\
\text { week; } \\
5 . \text { once or twice a } \\
\text { month; } \\
6 \text { 6.Less than once a } \\
\text { month; } \\
\text { 7. Not at all in last } \\
3 \text { month }\end{array}$ & $\begin{array}{l}\text { 1.None or less } \\
\text { once a month, } \\
2 . \text { Once a month, } \\
3.2-3 \text { times a } \\
\text { month } \\
\text { 4.Once a week, } \\
5.2-3 \text { times a } \\
\text { week, } \\
6.4-5 \text { times a } \\
\text { week, } \\
7 . \text { Once a day } 8 . \\
\text { more than twice a } \\
\text { day }\end{array}$ & 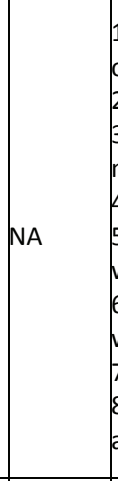 & $\begin{array}{l}\text { 1.None or less } \\
\text { once a month, } \\
\text { 2.Once a month } \\
\text { 3.2-3 times a } \\
\text { month } \\
\text { 4.Once a week, } \\
\text { 5. } 2-3 \text { times a } \\
\text { week, } \\
6.4-5 \text { times a } \\
\text { week, } \\
\text { 7.Once a day } \\
\text { 8.More than twice } \\
\text { a day }\end{array}$ & $\begin{array}{l}\text { 1. Every day, } \\
2.5-6 \text { days per } \\
\text { week, } \\
3.3-4 \text { days per } \\
\text { week, } \\
\text { 4.1-2 days per } \\
\text { week, } \\
5 . \text { several times } \\
\text { per month, } \\
6 . \text { not at all }\end{array}$ & 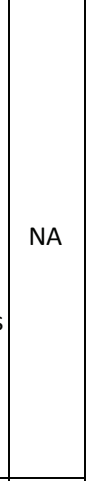 & NA & NA & $\begin{array}{l}\text { \# days } \\
\text { per } \\
\text { week }\end{array}$ \\
\hline $\begin{array}{l}\text { Frequency } \\
\text { : type }\end{array}$ & $\begin{array}{l}\text { Any } \\
\text { alcoholic }\end{array}$ & NA & $\begin{array}{l}\text { Any } \\
\text { alcoholic }\end{array}$ & $\begin{array}{l}\text { Any } \\
\text { alcoholic }\end{array}$ & Any alcoholic & Any alcoholic & $\begin{array}{l}\text { 1. So-ju (korean } \\
\text { liquor), } \\
\text { 2. Beer, } \\
\text { 3. M-akgeolli (rice } \\
\text { wine), } \\
\text { 4. Whisky, } \\
\text { 5. Wine } \\
\end{array}$ & NA & $\begin{array}{l}\text { 1.Liquor, } \\
\text { 2. Beer, } \\
\text { 3. Wine or rice } \\
\text { wine }\end{array}$ & Any alcoholic & NA & NA & NA & $\begin{array}{l}\text { Any } \\
\text { alcoholi } \\
\text { c }\end{array}$ \\
\hline $\begin{array}{l}\text { Quantity : } \\
\text { time span }\end{array}$ & \begin{tabular}{|l} 
Last 3 \\
months
\end{tabular} & NA & $\begin{array}{l}\text { Last } 7 \text { days } \\
\text { (drank most) }\end{array}$ & $\begin{array}{l}\text { Last } 7 \\
\text { days/\# per } \\
\text { week }\end{array}$ & NA & Last 3 months & $\begin{array}{l}\text { Last year: how } \\
\text { many glasses } \\
\text { drink at a time }\end{array}$ & $\begin{array}{l}\text { last } 30 \\
\text { days }\end{array}$ & $\begin{array}{l}\text { 1. In the last year, } \\
\text { 2. Last time you } \\
\text { drink }\end{array}$ & $\begin{array}{l}\text { Last } 6 \text { months } \\
\text { (not ask in w2 } \\
5 \text { cities) }\end{array}$ & NA & NA & NA & $\begin{array}{l}\text { Last } 3 \\
\text { month }\end{array}$ \\
\hline $\begin{array}{l}\text { Quantity: } \\
\text { type }\end{array}$ & $\begin{array}{l}\text { Any } \\
\text { alcoholic }\end{array}$ & NA & $\begin{array}{l}\text { 1.Normal } \\
\text { beer, } \\
\text { 2.Strong } \\
\text { beer, } \\
\text { 3.Spirits, } \\
\text { 4.sherry/ } \\
\text { martini, } \\
\text { 5.Wine, } \\
\text { 6.Alcoholic } \\
\text { Soft drink }\end{array}$ & $\begin{array}{l}\text { 1. Beer, } \\
\text { 2. Spirits } \\
\text { 3. Wine, }\end{array}$ & NA & Any alcoholic & $\begin{array}{l}\text { 1. So-ju(Korean } \\
\text { liquor), } \\
\text { 2. Beer, } \\
\text { 3.Makgeolli(rice } \\
\text { wine), } \\
\text { 4. Whisky and } \\
\text { other liquors, } \\
\text { 5. Wine }\end{array}$ & $\begin{array}{l}\text { any } \\
\text { alcoholic }\end{array}$ & $\begin{array}{l}\text { 1.Liquor, } \\
\text { 2.Beer, } \\
\text { 3.Wine or rice } \\
\text { wine }\end{array}$ & $\begin{array}{l}\text { 1.Beer, } \\
\text { 2.Shochu, } \\
\text { 3.Sake, } \\
\text { 4.Whiskey, } \\
\text { 5.Wine (not } \\
\text { ask in w2 } \\
\text { 5cities) }\end{array}$ & NA & NA & NA & $\begin{array}{l}\text { Any } \\
\text { alcoholi } \\
\text { c }\end{array}$ \\
\hline
\end{tabular}




\subsection{Measures for Physical Activity}

All surveys ask about physical activity. Most surveys ask different types of physical activities, including vigorous, moderate, or mild, but the KLoSA and JSTAR do not. The KLoSA asks whether respondents worked out more than once a week and the frequency and duration of exercise. The JSTAR surveys minutes of exercise during the weekday and weekend. Surveys also differ in their questions about time span and frequency of exercise. Table 3 summarizes the differences.

\subsubsection{Vigorous physical activity}

All the surveys except the KLoSA and the JSTAR ask about vigorous physical activities but differ in questions on time span and frequency of such exercise. For time span, most surveys do not ask specific time span of exercise. TILDA and IFLS ask about exercise in the last 7 days and CHARLS asks about it in a usual week. TILDA, CHARLS, and IFLS also ask whether the exercise was at least 10 continuous minutes. The MHAS asks about exercise in the past two years. The HRS, ELSA, SHARE, and LASI all ask the frequency of exercise using identical categories. TILDA, CHARLS, and IFLS ask number of days exercise per week while the MHAS only asks whether respondent exercise three or more times per week.

\subsubsection{Moderate physical activity}

Questions on moderate physical activity also differ on time span and frequency. The KLoSA, JSTAR, and MHAS do not survey moderate physical activity. Most surveys asking about such activity do not specify the time span, while TILDA, CHARLS, and IFLS refer to the last 7 days. The HRS, ELSA, SHARE, and LASI all ask the frequency of such exercise using nearly identical categories. TILDA, CHARLS, and IFLS ask number of days per week for such exercise.

\subsubsection{Mild physical activity}

The HRS, ELSA, CHARLS, TILDA, and IFLS ask about mild physical activity. Here, too, questions differ on time span and frequency of exercise. Most surveys do not ask the time span of such exercise while TILDA, CHARLS, and IFLS reference the last 7 days. The HRS and ELSA survey the frequency of exercise using identical categories while TILDA, CHARLS, and IFLS ask number of days per week for such exercise. 
Table 3. Summary of Physical Exercise Variables in Each Survey

\begin{tabular}{|c|c|c|c|c|c|c|c|c|c|c|}
\hline Exercise & HRS & ELSA & SHARE & KLoSA & LASI & CHARLS & JSTAR & TILDA & IFLS & MHAS \\
\hline Mild & Yes & Yes & NA & NA & NA & Yes & NA & Yes & Yes & NA \\
\hline Answers & $\begin{array}{l}\text { 1.More than } \\
\text { once a week, } \\
\text { 2.Once a } \\
\text { week, } \\
\text { 3.1-3 times a } \\
\text { month, } \\
\text { 4.Hardly ever } \\
\text { or never, } \\
\text { 7.Every day }\end{array}$ & $\begin{array}{l}\text { 1.More } \\
\text { than once } \\
\text { a week, } \\
2 . \text { Once a } \\
\text { week, } \\
\text { 3.1-3 times } \\
\text { a month, } \\
\text { 4.Hardly } \\
\text { ever or } \\
\text { never }\end{array}$ & $\begin{array}{l}\text { 1.More than } \\
\text { once a } \\
\text { week, } \\
\text { 2.Once a } \\
\text { week, } \\
\text { 3.1-3 times } \\
\text { a month, } \\
\text { 4. Hardly } \\
\text { ever or } \\
\text { never }\end{array}$ & NA & $\begin{array}{l}\text { 1.Everyday, } \\
\text { 2.More } \\
\text { than once a } \\
\text { week, } \\
\text { 3.Once a } \\
\text { week, } \\
4.1-3 \text { times } \\
\text { a month, } \\
\text { 5.Harly } \\
\text { ever or } \\
\text { never }\end{array}$ & $\begin{array}{l}\text { \# days } \\
\text { per week }\end{array}$ & NA & $\begin{array}{l}\text { \# days } \\
\text { per week }\end{array}$ & $\begin{array}{l}\text { \# days } \\
\text { per } \\
\text { week }\end{array}$ & $\begin{array}{l}3 \text { or } \\
\text { more } \\
\text { times a } \\
\text { week: } \\
\text { yes or } \\
\text { no }\end{array}$ \\
\hline
\end{tabular}




\section{USING MEASURES CROSS-COUNTRY ANALYSIS}

Having summarized the approaches the surveys take to health-behavior questions, in this section we propose harmonized measures of health behavior that can be used for cross-country analysis. Several tables summarize our comparison, where " $C$ " indicates comparability with the HRS measure, " $C 2$ " indicates another set of comparable measures, " $D$ " means "Different," and "NA" means "Not asked". The exact questions wording are in section 4.

\subsection{Measure of smoking behavior}

\subsubsection{Ever Smoke}

All surveys ask respondents about previous smoking. They differ in time span and type of tobacco products the respondent smoked. For time span, most surveys ask respondents whether they "ever" smoked, but the SHARE and TILDA ask respondents whether they smoked daily for at least one year, the JSTAR asks them whether they ever smoked "regularly," and the KLoSA asks respondents whether they ever smoked more than five packs. As a result, the measures of previous smoking behavior from the SHARE, TILDA, and JSTAR might be under-estimates due to shorter time spans considered and the KLoSA may yield an underestimate due to its higher threshold. The HRS, ELSA and MHAS only consider the cigarettes and not other types of tobacco while other surveys include different types of tobaccos. As a result, the HRS, ELSA, and MHAS may underestimate past tobacco use.

\subsubsection{Smoke now}

All surveys ask respondents whether they currently smoke cigarettes. Most surveys ask for a simple yes or no answer, but LASI and JSTAR collect further details by offering multiple response categories. Despite this variation, this measure is comparable across all countries.

\subsubsection{Quantity of currently smoke}

All surveys ask the quantity currently smoked, with some variations in time span and types of tobaccos. Most surveys ask about consumption in one day. ELSA differentiates between weekends and weekdays. LASI allows respondents to specify consumption in a day, week, or month. The surveys also differ in questions about the types of tobacco consumed: The HRS, KLOSA, CHARLS, JSTAR, and MHAS only ask about cigarettes, while the ELSA, SHARE, TILDA, and IFLS ask about different type of tobaccos. To calculate the quantity currently smoked, the amounts will be summed up for all types. The measure 
for HRS, KLOSA, CHARLS, JSTAR, and MHAS might yield underestimates relative to the other surveys due to their focus on cigarettes.

\subsubsection{History of smoking}

All the surveys except the ELSA ask several questions about smoking history, including when respondents started or stopped smoking. This measure is comparable across surveys asked.

\subsubsection{Quantity when smoked the most}

Only three surveys, the HRS, KLoSA, and MHAS, ask respondent about peak cigarette consumption. This question is comparable across these three surveys.

\subsection{Measure of drinking behavior}

\subsubsection{Ever Drink}

All the studies except TILDA and IFLS ask whether the respondent has ever drunk alcohol but differ in time span. Most surveys ask respondents whether they "ever" drank. The ELSA asks about consumption in the past 12 months, the JSTAR and wave 1 of the SHARE asks about the past six months, and waves 2 and 4 of the SHARE ask about the past three months.

\subsubsection{Frequency of drinking}

All studies except the ELSA wave 1, LASI, IFLS, and TILDA ask the frequency of drinking when the respondent consumed alcoholic drinks. However, there are significant variations in time span, option of answers, and type of drink. For time span, the HRS, SHARE waves 2 and 4, and MHAS specify the last three months. ELSA waves 2, 3, and 4 use the time span of the last seven day. SHARE wave 1 and the JSTAR use the time span of 6 months. KLoSA and CHARLS use the time span of last year. The HRS, ELSA waves 2, 3, and 4, and MHAS ask respondents the number of days they drink per week, while the SHARE, KLOSA CHARLS, and JSTAR offer the respondents answer categories. For different type of drinks, most surveys except KLoSA and CHARLS refer to any alcoholic beverages.

Table 4 summarizes comparability of variables on frequency of respondent drinking. Measures in the HRS and MHAS are comparable in asking about number of days of consumption in an average week over the past three months. We consider the measure in ELSA waves 2 through 5asking about the number of days of consumption in the past seven to be comparable as well, though it may yield an 
underestimate relative to the HRS and MHAS. The measures in the SHARE, KLOSA, CHARLS and JSTAR are also comparable, given their similar answer categories.

Table 4. Frequency of Drinking Variable Comparison

\begin{tabular}{|c|c|c|c|c|c|c|c|c|c|c|c|c|}
\hline \multirow{3}{*}{\begin{tabular}{|l} 
\\
$\begin{array}{l}\text { Frequency: } \\
\text { time span }\end{array}$ \\
\end{tabular}} & \multirow{3}{*}{\begin{tabular}{|l} 
HRS \\
last 3 \\
months \\
\end{tabular}} & \multicolumn{2}{|c|}{ ELSA } & \multicolumn{2}{|c|}{ SHARE } & \multirow{3}{*}{$\begin{array}{l}\text { KLoSA } \\
\text { last year: } \\
\text { month or week }\end{array}$} & \multirow{3}{*}{$\begin{array}{l}\text { LASI } \\
\text { NA }\end{array}$} & \multirow{3}{*}{$\begin{array}{l}\text { CHARLS } \\
\text { last year: } \\
\text { month or week }\end{array}$} & \multirow{3}{*}{$\begin{array}{l}\text { JSTAR } \\
\text { last } 6 \text { months }\end{array}$} & \multirow{3}{*}{$\begin{array}{l}\text { TILDA } \\
\text { NA }\end{array}$} & \multirow{3}{*}{ NA } & \multirow{3}{*}{$\begin{array}{l}\text { MHAS } \\
\text { last } 3 \\
\text { month }\end{array}$} \\
\hline & & \multirow{2}{*}{$\begin{array}{l}\text { W1 } \\
\text { NA }\end{array}$} & \multirow{2}{*}{$\begin{array}{l}\mathrm{W} 2,3,4,5 \\
\text { last } 7 \\
\text { days }\end{array}$} & \multirow{2}{*}{$\begin{array}{ll}5 \text { W1 } \\
\text { last } 6 \text { months }\end{array}$} & \multirow{2}{*}{$\begin{array}{l}\text { W2, W4 } \\
\text { last } 3 \text { months }\end{array}$} & & & & & & & \\
\hline & & & & & & & & & & & & \\
\hline $\begin{array}{l}\text { Frequency: } \\
\text { answer }\end{array}$ & $\begin{array}{l}: \# \text { days } \\
\text { per week }\end{array}$ & NA & $\begin{array}{l}\text { \# days } \\
\text { per } \\
\text { week }\end{array}$ & $\begin{array}{l}1 \text { Almost every } \\
\text { day; } 2.5-6 \text { days a } \\
\text { week; } 3.3-4 \text { days } \\
\text { a week; } 4 . \text { Once } \\
\text { or twice a week; } \\
\text { 5.once or twice a } \\
\text { month; } \\
6 . \text { Less than once } \\
\text { a month; } \\
7 . \text { Not at all in last } \\
6 \text { months }\end{array}$ & $\begin{array}{l}1 \text { Almost every } \\
\text { day, } 2.5-6 \text { days a } \\
\text { week; } 3.3-4 \\
\text { days a week; } \\
\text { 4.Once or twice a } \\
\text { week; } 5 . \text { once or } \\
\text { twice a month; } \\
\text { 6.Less than once } \\
\text { a month; } \\
\text { 7. Not at all in } \\
\text { last } 3 \text { month }\end{array}$ & $\begin{array}{l}\text { 1.none or less } \\
\text { once a month, } \\
\text { 2.once a } \\
\text { month,3.2-3 } \\
\text { times a month } \\
\text { 4.once a week, } \\
5.2-3 \text { times a } \\
\text { week, } 6.4-5 \\
\text { times a week, } \\
\text { 7.once a day } \\
\text { 8. more than } \\
\text { twice a day }\end{array}$ & NA & $\begin{array}{l}\text { 1.none or less } \\
\text { once a month, } \\
\text { 2.once a } \\
\text { month, 3.2-3 } \\
\text { times a month } \\
\text { 4.once a week, } \\
5.2-3 \text { times a } \\
\text { week, 6. 4-5 } \\
\text { times a week, } \\
\text { 7.once a day } 8 . \\
\text { more than } \\
\text { twice a day }\end{array}$ & $\begin{array}{l}\text { 1. Every day, } \\
\text { 2.5-6 days } \\
\text { per week, } \\
\text { 3.3-4 days } \\
\text { per week, } \\
4.1-2 \text { days } \\
\text { per week, } \\
\text { 5.several } \\
\text { times per } \\
\text { month, } \\
6 . \text { not at all }\end{array}$ & NA & NA & $\begin{array}{l}\text { \# days } \\
\text { per week }\end{array}$ \\
\hline $\begin{array}{l}\text { Frequency: } \\
\text { type }\end{array}$ & $\begin{array}{l}\text { :any } \\
\text { alcoholic }\end{array}$ & NA & $\begin{array}{l}\text { any } \\
\text { alcoholic }\end{array}$ & any alcoholic & any alcoholic & $\begin{array}{l}\text { 1. So-ju } \\
\text { (korean liquor), } \\
\text { 2.Beer, 3.M- } \\
\text { akgeolli (rice } \\
\text { wine), } \\
\text { 4.whisky, } \\
\text { 5.wine }\end{array}$ & NA & $\begin{array}{l}\text { 1.liquor, } \\
\text { 2.beer, 3.wine } \\
\text { or rice wine }\end{array}$ & any alcoholic & NA & NA & $\begin{array}{l}\text { any } \\
\text { alcoholic }\end{array}$ \\
\hline
\end{tabular}

\subsubsection{Quantity of drinking}

Most studies ask respondents about consumption, but ELSA wave 1, SHARE wave 1, IFLS, and TILDA do not. There are also differences in how surveys count drinks, the time span they consider, and the type of drink they consider. To count drinks, ELSA waves 2 and 3 asks respondents the number of drinks they had on the day they drank the most while other surveys refer to an average, typically daily. For time span, HRS, SHARE waves 2 and 4, and MHAS refer to the last three months. ELSA refers to the last seven days, but in waves 2 and 3 asks about the day of most consumption. KLoSA and CHARLS refer to the last year while LASI refers to the last 30 days. HRS, SHARE waves 2 and 4, LASI, and MHAS do not specify types of drink, while ELSA wave 2 through 5, KLoSA, CHARLS, and JSTAR do so.

Altogether, we consider quantity of alcohol consumption variables to be comparable in the HRS, SHARE waves 2 and 4, LASI, and MHAS, although LASI considers a shorter time span for daily consumption and may therefore yield an underestimate relative to the others. The quantity of alcohol 
consumption measures in ELSA waves 2 and 4, KLOSA, CHARLS and JSTAR, have different time span and ask different type of alcoholic. The measure among these surveys is similar but not comparable. Table 5 summarizes the measures on quantity of drinking and their comparability.

Table 5. Quantity of Drinking Variable Comparison

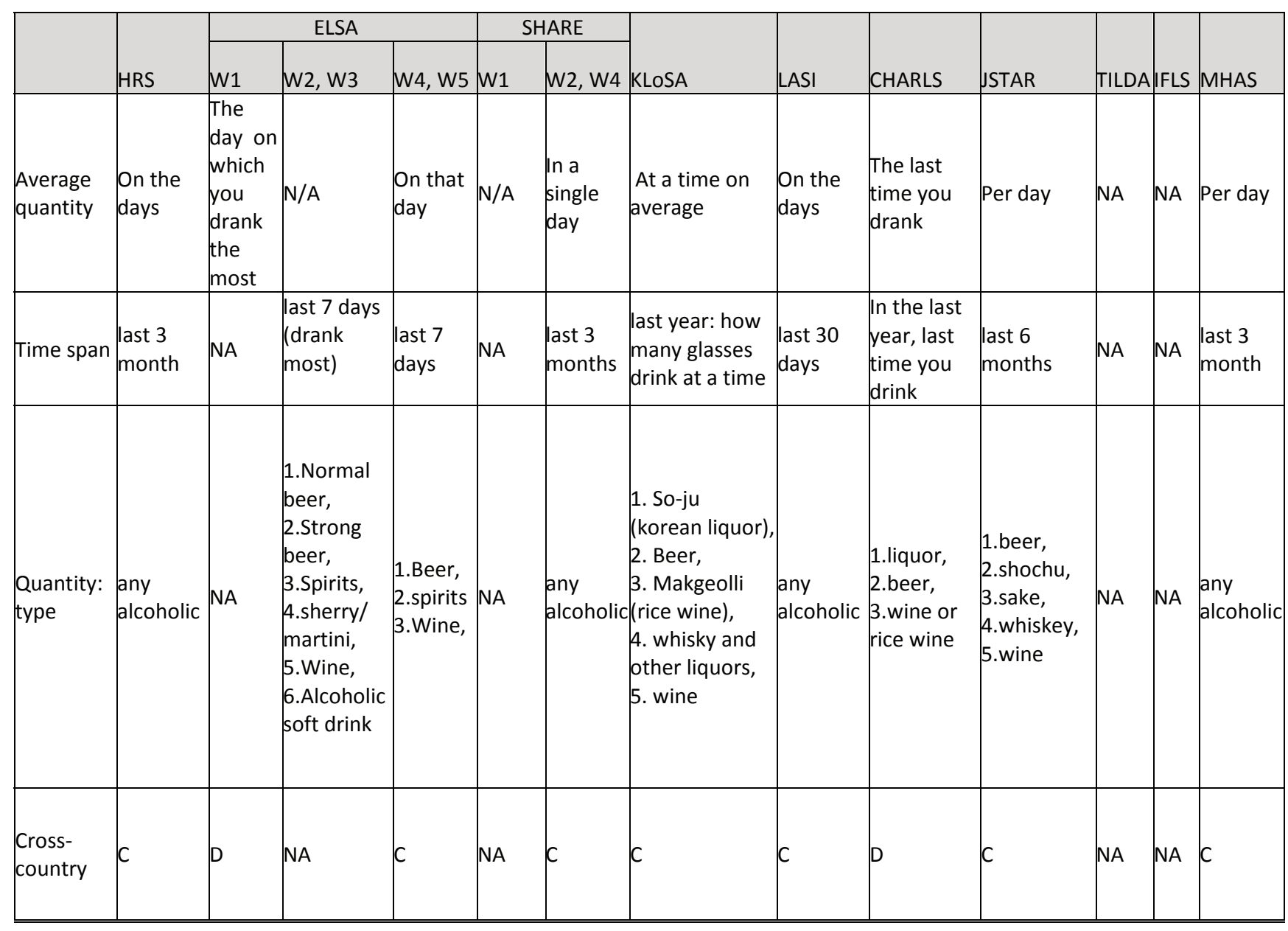

C: comparable; NA: not asked; D: different 


\subsection{Measure of Physical activities}

\subsubsection{Vigorous Exercise}

All the surveys except the KLOSA and JSTAR ask about vigorous exercise but differ in the time span and frequencies they consider. Most surveys do not specify time span, but TILDA and IFLS ask about vigorous exercise in the last 7 days, the CHARLS asks about it in a usual week, while the MHAS asks about it in the last two years. The CHARLS, TILDA and IFLS also specify whether the duration of the exercise was at least 10 continuous minutes. Regarding frequency of exercise, the HRS, ELSA, SHARE and LASI use nearly identical categories, while the CHARLS, TILDA, and IFLS ask number of days per week. The MHAS only asks whether respondent exercise three or more times weekly.

We consider the measures on vigorous exercise to be comparable among HRS, ELSA, SHARE and LASI. The measures on vigorous exercise in the CHARLS, TILDA and IFLS are also comparable to each other. Table 6 summarizes the comparability of these measures.

Table 6. Vigorous Exercise Variable Comparison

\begin{tabular}{|c|c|c|c|c|c|c|c|c|c|c|}
\hline Exercise & HRS & ELSA & SHARE & KLoSA & LASI & CHARLS & JSTAR & TILDA & IFLS & MHAS \\
\hline $\begin{array}{l}\text { Vigorous: } \\
\text { time } \\
\text { span }\end{array}$ & not specific & not specific & not specific & NA & $\begin{array}{l}\text { not } \\
\text { specific }\end{array}$ & $\begin{array}{l}\text { in a usual } \\
\text { week, at } \\
\text { least } 10 \\
\text { mins }\end{array}$ & NA & $\begin{array}{l}\text { in last } 7 \\
\text { days, at } \\
\text { least } 10 \\
\text { mins }\end{array}$ & $\begin{array}{l}\text { in last } \\
7 \text { days, } \\
\text { at least } \\
10 \\
\text { mins }\end{array}$ & $\begin{array}{l}\text { last } 2 \\
\text { years }\end{array}$ \\
\hline $\begin{array}{l}\text { Vigorous: } \\
\text { frequenc } \\
\text { y }\end{array}$ & $\begin{array}{l}\text { 1.more } \\
\text { than once a } \\
\text { week, } \\
\text { 2.once a } \\
\text { week, } \\
\text { 3.1-3 times } \\
\text { a month, } \\
\text { 4.hardly } \\
\text { ever or } \\
\text { never, } \\
\text { 7.every day }\end{array}$ & $\begin{array}{l}\text { 1.more than } \\
\text { once a } \\
\text { week, } \\
\text { 2.once a } \\
\text { week, } \\
\text { 3.1-3 times } \\
\text { a month, } \\
\text { 4.hardly } \\
\text { ever or } \\
\text { never }\end{array}$ & $\begin{array}{l}\text { 1.more than } \\
\text { once a week, } \\
2 . \text { once a } \\
\text { week, } \\
3.1-3 \text { times a } \\
\text { month, } \\
\text { 4. hardly } \\
\text { ever or } \\
\text { never }\end{array}$ & NA & $\begin{array}{l}\text { 1.everyday } \\
\text {, } 2 . \text { more } \\
\text { than once } \\
\text { a week, } \\
\text { 3.Once a } \\
\text { week, } 4.1 \text { - } \\
3 \text { times a } \\
\text { month, } \\
5 . \text { Harly } \\
\text { ever or } \\
\text { never }\end{array}$ & $\begin{array}{l}\text { \# days per } \\
\text { week }\end{array}$ & NA & $\begin{array}{l}\text { \# days per } \\
\text { week }\end{array}$ & $\begin{array}{l}\text { \# days } \\
\text { per } \\
\text { week }\end{array}$ & $\begin{array}{l}3 \text { or } \\
\text { more } \\
\text { times a } \\
\text { week: } \\
\text { yes or } \\
\text { no }\end{array}$ \\
\hline $\begin{array}{l}\text { Cross- } \\
\text { country }\end{array}$ & C & C & C & NA & C & $\mathrm{C} 2$ & NA & $\mathrm{C} 2$ & $\mathrm{C} 2$ & D \\
\hline
\end{tabular}

C: comparable of frequency; C2: comparable of days; NA: not asked; D: different

\subsubsection{Moderate Exercise}

The measures on moderate exercise also differ in time span and frequency of exercise reported. These measures are comparable among HRS, ELSA, SHARE and LASI, which ask about the same time 
span and use nearly identical frequency of exercise categories. Another comparison among CHARLS, TILDA and IFLS is also possible because of the similarities in time span and number of days reported.

Table 7 summarizes comparability among these measures.

Table 7. Moderate Exercise Variable Comparison

\begin{tabular}{|c|c|c|c|c|c|c|c|c|c|c|}
\hline Exercise & HRS & ELSA & SHARE & KLoSA & LASI & CHARLS & JSTAR & TILDA & IFLS & MHAS \\
\hline $\begin{array}{l}\text { Moderate: } \\
\text { time span }\end{array}$ & not specific & not specific & not specific & NA & not specific & $\begin{array}{l}\text { in a usual } \\
\text { week, at } \\
\text { least } 10 \\
\text { mins }\end{array}$ & NA & $\begin{array}{l}\text { in last } 7 \\
\text { days, at } \\
\text { least } 10 \\
\text { mins }\end{array}$ & $\begin{array}{l}\text { in last } 7 \\
\text { days, at } \\
\text { least } 10 \\
\text { mins }\end{array}$ & NA \\
\hline answers & $\begin{array}{l}\text { 1.more than } \\
\text { once a week, } \\
\text { 2.once a week, } \\
\text { 3.1-3 times a } \\
\text { month, } \\
\text { 4.hardly ever } \\
\text { or never, } \\
\text { 7.every day }\end{array}$ & $\begin{array}{l}\text { 1.more than } \\
\text { once a week, } \\
2 . \text { once a } \\
\text { week, } \\
3.1-3 \text { times a } \\
\text { month, } \\
\text { 4.hardly ever } \\
\text { or never }\end{array}$ & $\begin{array}{l}\text { 1.more than } \\
\text { once a week, } \\
2 . \text { once a } \\
\text { week, } \\
\text { 3.1-3 times a } \\
\text { month, } \\
\text { 4. hardly ever } \\
\text { or never }\end{array}$ & NA & $\begin{array}{l}\text { 1.everyday, } \\
\text { 2.more than } \\
\text { once a week, } \\
\text { 3.once a } \\
\text { week, 4.1-3 } \\
\text { times a } \\
\text { month, } \\
\text { 5.hardly ever } \\
\text { or never }\end{array}$ & $\begin{array}{l}\text { \# days per } \\
\text { week }\end{array}$ & NA & $\begin{array}{l}\text { \# days per } \\
\text { week }\end{array}$ & $\begin{array}{l}\text { \# days } \\
\text { per week }\end{array}$ & NA \\
\hline $\begin{array}{l}\text { Cross- } \\
\text { country }\end{array}$ & C & C & C & NA & $\mathrm{C}$ & $\mathrm{C} 2$ & NA & $\mathrm{C} 2$ & $\mathrm{C} 2$ & NA \\
\hline
\end{tabular}

C: comparable of frequency; C2: comparable of days; NA: Not asked

\subsubsection{Mild Exercise}

Fewer surveys ask about mild exercise. Among those that do, there are differences in time span and frequency of exercise reported. This measure is comparable among HRS and ELSA because they consider the same time span and nearly identical frequency categories. Another comparison is possible among CHARLS, TILDA and IFLS because of the similarities in time span and number of days reported. Table 8 summarizes the comparability on these variables. 
Table 8. Mild Exercise Variable Comparison

\begin{tabular}{|c|c|c|c|c|c|c|c|c|c|c|}
\hline Exercise & HRS & ELSA & SHARE & KLoSA & LASI & CHARLS & JSTAR & TILDA & IFLS & MHAS \\
\hline $\begin{array}{l}\text { Mild: } \\
\text { time span }\end{array}$ & not specific & not specific & NA & NA & NA & $\begin{array}{l}\text { in a usual } \\
\text { week, at } \\
\text { least } 10 \\
\text { mins }\end{array}$ & NA & $\begin{array}{l}\text { in last } 7 \\
\text { days, at } \\
\text { least } 10 \\
\text { mins }\end{array}$ & $\begin{array}{l}\text { in last } 7 \\
\text { days, at } \\
\text { least } 10 \\
\text { mins }\end{array}$ & NA \\
\hline answers & $\begin{array}{l}\text { 1.more than once } \\
\text { a week, } 2 . \text { once a } \\
\text { week, } 3.1-3 \text { times } \\
\text { a month, } 4 . \text { hardly } \\
\text { ever or never, } \\
\text { 7.every day }\end{array}$ & $\begin{array}{l}\text { 1.more than } \\
\text { once a week, } \\
\text { 2.once a week, } \\
\text { 3.1-3 times a } \\
\text { month, 4.hardly } \\
\text { ever or never }\end{array}$ & NA & NA & NA & $\begin{array}{l}\text { \# days per } \\
\text { week }\end{array}$ & NA & $\begin{array}{l}\text { \# days per } \\
\text { week }\end{array}$ & $\begin{array}{l}\text { \# days per } \\
\text { week }\end{array}$ & NA \\
\hline $\begin{array}{l}\text { Cross- } \\
\text { country }\end{array}$ & C & C & NA & NA & NA & $\mathrm{C} 2$ & NA & $\mathrm{C} 2$ & $\mathrm{C} 2$ & NA \\
\hline
\end{tabular}

C: comparable of frequency; C2: comparable of days; NA: Not asked 


\section{QUESTION CONCORDANCE BY SURVEYS}

To facilitate the cross-country comparisons, this section lists out all health behavior question numbers and texts in each survey. At the end of this section, Table 9 lists the question numbers in each survey.

\subsection{Smoking}

\subsubsection{HRS}

LC116: Have you ever smoked cigarettes?

(By smoking we mean more than 100 cigarettes in your lifetime. Do not include pipes or cigars)

Answer: 1. Yes; 5. No

LC117: Do you smoke cigarettes now?

Answer: 1. Yes; 5 . No

LC118: About how many cigarettes or packs do you usually smoke in a day now?

LC119: About how many cigarettes or packs do you usually smoke in a day now? (This question refers to cigarette smoking only. If respondent smokes cigars or pipes, enter the type and amount smoked in an F2 comment)

Answer: Cigarettes per day; Or Packs per day

\subsubsection{ELSA}

HeSmk: Have you ever smoked cigarettes?

Answer: 1. Yes; 2 . No

HESka: Do you smoke cigarettes at all nowadays?

(If has ever smoked cigarettes: HeSmk =1)

Answer: 1. Yes; 2 . No

HECig: Do you smoke cigarettes or roll ups?

(If smokes cigarettes at all nowadays: HESka =1)

Answer: 1. Cigarettes; 2. Roll ups; 3. Both cigarettes and roll-ups 
HeSkb: About how many cigarettes a day do you usually smoke on weekdays? (If smokes cigarettes or cigarettes and roll-ups: HECig = 1 OR 3; If range given and can't estimate, enter mid-point; if less than one a day, enter 0 )

Answer: Range 0 to 997

HeSkc: About how many cigarettes a day do you usually smoke at weekends? (If range given and can't estimate, enter mid-point; If less than one a day, enter 0 )

(If smokes roll-ups or both cigarettes and roll-ups: HECig = 2 OR 3)

Answer: Range 0 to 997

HeTba: How much tobacco do you normally smoke on a weekday?

Answer: 1. Grams; 2. Ounces

HETbb: How much tobacco do you normally smoke on a weekday?

Answer: Range 0 to 997

HeTbc: How much tobacco do you normally smoke a day at weekends?

Answer: 1. Grams; 2. Ounces

HETbd: How much tobacco do you normally smoke a day at weekends?

Answer: Range 0 to 997

\subsubsection{SHARE}

BR001_: Have you ever smoked cigarettes, cigars, cigarillos or a pipe daily for a period of at least one year?

Answer: 1. Yes; 5 . No

BR002_: Do you smoke at the present time?

Answer: 1. Yes; 5. No, I have stopped

BR005_: What [do/did] [you] [smoke/smoke before you stopped]? 
(Code all that apply)

Answer: 1. Cigarettes; 2. Pipe; 3. Cigars or cigarillos

BR006_: How many cigarettes [do/did] [you] [smoke] on average per day?

(If 1. Cigarettes in BR005_)

Answer: Range 0 to 120

BR007_: How many pipes [do/did] [you] [smoke] on average per day?

(If 2. Pipe in BR005_)

Answer: Range 0 to 120

BR008_: How many cigars or cigarillos [do/did] [you] [smoke] on average per day?

(If 3. Cigars or cigarillos IN BR005_)

Answer: Range 0 to 120

\subsubsection{KLOSA}

C103: Have you ever smoked more than 5 packs of cigarettes (100 cigarettes)?

Answer: 1. Yes; 2 . No

C104: Do you smoke cigarettes now?

Answer: 1. Yes; 2. No

C105: About how many cigarettes or packs do you usually smoke in a day now? (IWER: One pack is 20 cigarettes. For example, mark 30 for one and a half packs)

Answer: cigarettes / day (Range: 1 to 100)

\subsubsection{LASI}

HT205: Have you ever smoked tobacco [cigarette, bidi, cigar, hookah] or used smokeless tobacco [such as chewing tobacco, gutka, pan masala, etc.]?

Answer: 1. Yes; 2. No 
HT206: Do you currently smoke, chew, or sniff tobacco or have you quit?

(If respondent has ever smoked tobacco or other types of tobacco listed in the previous question)

(Select all the apply)

Answer: 1. Yes, I chew or sniff tobacco product; 2. Yes, I smoke tobacco product; 3. No, I quit

HT207: Please tell me approximately how many grams of tobacco you normally consumed per day, including chewing tobacco, sniffing tobacco, and other tobacco. If it is easier you can tell me how many grams per week or per month.

(If respondent chews or sniffs tobacco products, HT206=1)

Answer: ___ grams per day/week/month

HT207b: How many times per day/week do you chew tobacco, pan masala, etc? (If HT027 is DK) (Allow interviewer to select either DAY or WEEK and put in a number Answer: per

day/week/month

HT208_intro: How many cigarettes, bidis, cigars, or packs do you usually smoke in a day?

(If respondent smokes tobacco products, HT206=2)

Answer: number of cigarettes $\mathrm{OR}$ number of packs

\subsubsection{CHARLS}

DA059. Have you ever chewed tobacco, smoked a pipe, smoked self-rolled cigarettes, or smoked cigarettes/cigars?

Answer:1 Yes 2 No

DA060. Which products did/do you normally use? Answer:

1.Smoking a pipe

2.Smoking self-rolled cigarettes

3.Filtered cigarette

4.Unfiltered cigarette

5.Cigar

6.Water cigarettes

DA061. Do you still have the habit or have you totally quit? 
Answer: 1still have; 2 Quit

DA063. In one day about how many cigarettes do/did you consume [preload:now/before totally quitting]? \# cigarettes

DA064. How much does/did it cost per pack = 20 cigarettes? _Yuan

[IWER: Prompt R: we're asking price at that time, not current price]

DA066. How soon after you wake up did/do you smoke your first cigarette, cigar, or pipe?

Answer:

(1) Within 5 minutes 5

(2) Within 6-30 minutes $6-30$

(3) Within 31-60 minutes $31-60$

(4) More than 1 hour

\subsubsection{JSTAR}

Tome21: Do you regularly use tobacco or did you use it in the past?

Answer: 1. Yes, I smoke now; 2. I smoked in the past, but I have quit; 3. No, I have never smoked regularly

Tom23: About how many cigarettes do you smoke per day?

Tom24: About how many packs do you smoke per day?

Tom25: About how many cigarettes do you smoke per day (include packs)?

\subsubsection{TILDA}

BH001: Have you ever smoked cigarettes, cigars, cigarillos or a pipe daily for a period of at least one year?

Answer:1. Yes (GO TO BH002); 5. No (GO TO BH101); 98. DK (GO TO BH101); 9. RF (GO TO BH101) 
BH002: Do you smoke at the present time?

(IWER: IF RESPONDENT SMOKED IN THE PAST 3 MONTHS CODE 1)

Answer:1. Yes (GO TO BH004); 5. No, I have stopped (GO TO BH003); 98. DK (GO TO BH003); 99. RF (GO

TO BH003)

BH004: For how many years [do/did] you smoke altogether?

Answer: 1 ... 100 ; 98. DK; 99. RF

BH005: What do/did you smoke (before you stopped)?

1. Cigarettes GO TO BH006 [bh005_1]

2. Pipe GO TO BH007 [bh005_2]

3. Cigars or cigarillos GO TO BH008 [bh005_3]

98. DK GO TO BH101 [bh005_4]

99. RF GO TO BH101 [bh005_5]

BH006: How many cigarettes do/did you smoke on average per day?

Answer: 1 ... 100; 98. DK ; 99. RF

BH007: How many pipes do/did you smoke on average per day?

Answer: 1 ... 100; 98. DK; 99. RF

BH008: How many cigars or cigarillos do/did you smoke on average per day?

Answer: 1 ... 100; 98. DK; 99. RF

\subsubsection{IFLS}

KM01a. Have you ever chewed tobacco, smoked a pipe, smoked self-rolled cigarettes, or smoked cigarettes/cigars?

Answer:

No …….................. 3

Yes........................ 1

KM01b. Chewing tobacco 
Answer:

1. Yes

3. No

KM01c. Smoking a pipe

1. Yes

3. No

KM01d. Smoking self-rolled cigarettes

Answer:

1. Yes

3. No

KM01e. Smoking cigarettes/cigars

1. Yes

3.No

KM02. INTERVIEWER'S CHECK KM01e:

DOES KM01e=1 (SMOKING

CIGARETTES/CIGARS)?

Answer:

NO........................... 3 KMO4

YES......................... 1

KM03. Are the cigarettes classified as: ANSWER MAY BE MORE THAN ONE

Answer:

Filtered cigarette ......................A

Unfiltered cigarette ....................

Filtered cloves cigarette .............. C

Unfiltered cloves cigarette ........... D

Cigar ....................................... 
KM04. Do you still have the habit or have you totally quit?

Answer:

STILL HAVE

$1 \mathrm{KM} 05 \mathrm{~b}$

QUIT .3

KM05b. INTERVIEWER CHECK KM01b KM01c KM01d:

DOES KM01b=1 or $\mathrm{KM} 01 \mathrm{c}=1$ or $\mathrm{KM} 01 \mathrm{~d}=1$

(CHEWING TOBACCO/SMOKING A PIPE)?

Answer:

NO.............................. 3 KM07

YES............................ 1

KM06. In one week how many ounces (100 grams) did/do you consume now/before totally quitting of chewing tobacco and smoking pipe?

Answer:

$\left\llcorner\perp \mathrm{OZ}_{\mathrm{OZ}}(100 \mathrm{gr})\right.$............... 1

DON'T KNOW.................... 8

KM06a. INTERVIEWER CHECK KM04=1

Answer:

NO...................................... KM07

YES.................................1

KM06b. What's the price for 1 ounce you have to pay?

Answer:

$\left\llcorner\perp \perp \_,\left\llcorner\perp \_ \text {Rp...... } 1\right.\right.$

DON'T KNOW................... 8

KM07. INTERVIEWER CHECK KM01d AND KM01e:

DOES KM01d=1 OR KM01e=1 (SMOKING

SELF-ROLLED CIGARETTES / 


\section{CIGARETTES/CIGARS)?}

Answer:

NO. $.3 \mathrm{KM}$

KM08. In one day about how many cigars/cigarettes did you consume now/before totally quitting? Answer:

$\llcorner\perp$ per day ...........................1

DON'T KNOW...........................

KM08a. INTERVIEWER CHECK KM04=1

Answer:

NO $3 \mathrm{KM} 09$

YES 1

KM08f. INTERVIEWER CHECK KMOe=1

Answer:

NO 3 KM09

YES. 1

KM08b. How many cigarettes/packs do you usually buy each time?

Answer:

$\left\llcorner\perp \_\right.$cigarettes......................1 KM08d

$\llcorner\perp$ packs.............................

KM08c. How many cigarettes for each pack?

Answer:

$\left\llcorner\perp \_\right.$cigarettes

KM08d. How much did you spend each time?

Answer:

$\left\llcorner\perp \perp \_,\llcorner\perp \text { Rp. ............1 }\right.$

DON'T KNOW......................... 
KM08e. What is the brand of cigarettes do you usually purchase?

Answer:

Gudang Garam Merah .............. 01

Gudang Garam Surya ............... 02

Gudang Garam International..... 03

Sampoerna A Mild ...................... 04

Sampoerna Hijau......................... 05

Djarum Super............................ 06

Djarum 76 Kretek....................... 07

Bentoel Filter............................. 08

Bentoel Kretek tanpa filter ......... 09

Ardath ........................................ 10

Marlboro..................................... 11

Marlboro Kretk Filter ................. 12

Lucky Strike ............................. 13

Kansas........................................ 14

Dji Sam Soe............................... 15

Lainnya, sebutkan...................... 95

KM09. About how much money did/do you spend each week on these products?

Answer:

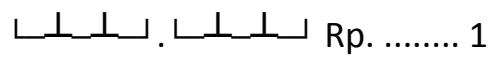

DON'T KNOW........................ 8

KM11. How soon after you wake up did/do you smoke your first cigarette, cigar, or pipe?

Answer:

Within 5 minutes ..................... 1

Within 6-30 minutes ................. 2

Within $31-60$ minutes ................ 3

More than 1 hour...................... 4

DON'T KNOW........................... 8 


\subsubsection{MHAS}

C.54 Have you ever smoked cigarettes?

Answer:

1. Yes

2. No

C.55 Do you smoke cigarettes now? INCLUDE MORE THAN 100 CIGARETTES OR 5 PACKS IN YOUR LIFETIME. DO NOT INCLUDE PIPES OR CIGARS.

Answer:

YES ……............................ 1

NO

$\mathrm{RF}$....................................... 8

DK.......................................... 9

Go to C.60

C.56 About how many cigarettes or packs do you usually smoke in a day?

CIGARETTES/DAY

OR

PACKS/DAY

I.

Answer:

87 OR MORE CIGARETTES 87

$\mathrm{RF}$ 88

DK 99

\subsection{Drinking}

\subsubsection{HRS}

LC128 EVER DRINK ALCOHOL

Do you ever drink any alcoholic beverages such as beer, wine, or liquor?

Answer:

1. YES

3. [VOL] Never have used alcohol 
5. NO

LC129 NUMBER DAYS PER WEEK- DRINK ALCOHOL

In the last three months, on average, how many days per week have you had any

alcohol to drink? (For example, beer, wine, or any drink containing liquor.)

Answer: USE 0 for none or less than once a week

Range: $1-6$,

7 every day

LC130 NUMBER DRINKS- PER DAY

In the last three months, on the days you drink, about how many drinks do you have?

Answer:

\# drinks:

\subsubsection{ELSA}

Wave 1

HeAla

In the past 12 months have you taken an alcoholic drink ...READ

OUT...

Answer:

1 twice a day or more,

2 daily or almost daily,

3 once or twice a week,

4 once or twice a month,

5 special occasions only,

6 or, not at all?

Wave 2 and Wave 3

SCAKO

Thinking now about all kinds of drink, how often have you had an alcoholic drink of any kind in the last 12 months?

1 Almost every day 
2 Five or six days a week

3 Three or four days a week

4 Once or twice a week

5 Once or twice a month

6 Once every couple of months

7 Once or twice a year

8 Not at all in the last 12 months

IF had alcohol in the last 12 months : Scako $<>96$

SCAL7A Did you have an alcoholic drink in the seven days ending yesterday?

1 Yes

2 No

IF had alcohol in the last 7 days : Scal7a $=1$

SCAL7B On how many days out of the last seven did you have an alcoholic drink?

1 One

2 Two

3 Three

4 Four

5 Five

$6 \operatorname{Six}$

7 Seven

Please think about the day in the last week on which you drank the most. (If you drank the same amount on more than one day, please answer about the most recent of those days.) From the list, please tick all the types of alcoholic drinks which you drank on that day. For the ones you drank, write in how much you drank on that day. EXCLUE NON-ALCOHOLIC OR LOW-ALCOHOL DRINKS, EXCEPT SHANDY SCDRI Please tick all drinks drunk on that day

1 Normal strength beer, lager, stout, cider or shandy (less than 6\% alcohol) - excludes bottles/cans of shandy

2 Strong beer, lager, stout or cider (6\% alcohol or more, such as Tennants, Extra, | | Special Brew, Diamond White) 
3 Spirits or liqueurs, such as gin, whisky, rum, brandy, vodka, or cocktails

4 Sherry or martini (including port, vermouth, cinzano, dubonnet)

5 Wine (including babycham and champagne)

6 Alcoholic soft drinks or 'alcopops' (such as Barcardi Breezer, Smirnoff Ice)

7 Other (a)

8 Other (b)

IF drank other (a) alcohol on heaviest day of drinking : [Scdri = 7]

SCDRI07 Write in name of drink

Text: up to 20 characters

IF drank other (b) alcohol on heaviest day of drinking : [Scdri = 8]

SCDRI08 Write in name of drink

Text: up to 20 characters

IF drank normal strength beer : Scdri $=1$

SCABNP How many pints of normal strength beer were drunk on that day?

Range: 0 to 30

SCABNLC How many large cans or bottles of normal strength beer were drunk on that day?

Range: 0 to 30

SCABNSC How many small cans or bottles of normal strength beer were drunk on that day?

Range: 0 to 30

IF drank strong beer : Scidri $=2$

SCABSP How many pints of strong beer were drunk on that day?

Range: 0 to 30

SCABSP How many large cans or bottles of strong beer were drunk on that day?

Range: 0 to 30 
SCABNSC How many small cans or bottles of strong beer were drunk on that day?

Range: 0 to 30

IF drank spirits or liqueurs : Scidri $=3$

SCASPIR How many glasses of spirits or liqueurs were drunk on that day (?

Range: 0 to 30

IF drank sherry or martini : Scidri $=4$

SCASHER How many glasses of sherry or martini were drunk on that day

Range: 0 to 30

IF drank wine : Scidri = 5

SCAWIN How many glasses of wine were drunk on that day?

Range: 0 to 30

IF drank alcoholic soft drinks or 'alcopops' : Scidri = 6

SCAPOPGHow many small cans or bottles of alcoholic soft drink or 'alcopop' were drunk on that day?

Range: 0 to 30

\section{WAVE $4 \& 5$}

SCAKO: Thinking now about all kinds of drink, how often have you had an alcoholic drink of any kind in the last 12 months?

1 Almost every day;

2. Five or six days a week;

3. Three or four days;

4. Once or twice a week;

5. once or twice a month;

6. Once every couple of months;

7. Once or twice a year;

8. not at all in last 12 months

SCAL7A: Did you have an alcoholic drink in the seven days ending yesterday? 
Answer: 1.yes; 2.no

(SAME AS W2, W3) SCAL7B: IF had alcohol in the last 7 days : Scal7a $=1$, On how many days out of the last seven did you have an alcoholic drink?

1. one

2.two

3.three

4. four

5. five

6. six

7. seven

SCDRSPI: During the last seven days, how many measures of spirits did you have? Drinks poured at home may be larger than a pub single measure - please estimate number of signles. drinks

SCDRWIN: During the last seven days, how many glasses of wine did you have? Include sherry, port, vermouth. drinks

SCDRPIN: During the last seven days, how many pints of beer, lager or cider did you have? drinks

\subsubsection{SHARE}

\section{WAVE 1}

BR010_BEVERAGES CONSUMED LAST 6 MONTHS

I am now going to ask you a few questions about what you drink - that is if you drink. Please look at card 11. During the last six months, how often have you drunk any alcoholic beverages, like beer, cider, wine, spirits or cocktails?

1. Almost every day

2. Five or six days a week

3. Three or four days a week

4. Once or twice a week 
5. Once or twice a month

6 . Less than once a month

7. Not at all in the last 6 months

IF BR010_(BEVERAGES CONSUMED LAST 6 MONTHS) < 7. Not at all in the last 6 months BR011_FREQ MORE THAN 2 GLASSES BEER IN A DAY

Please look at card 11. During the last six months, how often have you had more than two glasses or cans of beer or cider in a single day?

1. Almost every day

2. Five or six days a week

3. Three or four days a week

4. Once or twice a week

5. Once or twice a month

6. Less than once a month

7. Not at all in the last 6 months

BR012_FREQ MORE THAN 2 GLASSES WINE IN A DAY

(Please look at card 11.) During the last six months, how often have you had more than two glasses of wine in a single day?

1. Almost every day

2. Five or six days a week

3. Three or four days a week

4. Once or twice a week

5. Once or twice a month

6. Less than once a month

7. Not at all in the last 6 months

BR013_FREQ MORE THAN 2 HARD LIQUOR IN A DAY

(Please look at card 11.) During the last six months, how often have you had more than two cocktails or drinks of hard liquor in a single day?

1. Almost every day 
2. Five or six days a week

3. Three or four days a week

4. Once or twice a week

5. Once or twice a month

6. Less than once a mont $h$

7. Not at all in the last 6 months

WAVE 2 , Wave 3 and WAVE 4

BR010_: During the last three months, how often have you drunk any alcoholic beverages, like beer, cider, wine, spirits or cocktails?

1. Almost every day;

2. Five or six days a week;

3. Three or four days;

4. Once or twice a week;

5. once or twice a month;

6 . Less than once a month;

7. Not at all in last 3 months

BR021_if BR010=7,.don't know or refusal: Have you ever drunk alcoholic beverages? 1.yes, 5. No

BR019_: In the last three months, on the days you drink, about how many drinks do you have? days : $1-$ 70

\subsubsection{Klosa}

WAVE 1

C109. Do you ever drink any alcoholic beverages, such as beer, wine, or liquor?

[1]. Yes

[5]. No

C110. Have you never had alcoholic beverages due to some reasons (e.g., religious, health related, etc), or you used to have some drinks in the past?

[1].No, I never had a drink 
[5].Yes, I used to drink

C111. Do you still drink?

[1].Yes, I drink from time to time

[5]. No, I quit drinking

C115. Now, I am going to ask you how often and how much you drink during the past year. Please tell me how often you drank per month, and how much you drank at a time on average. I will repeat the questions for different types of alcoholic beverage.

C116. So-ju (Korean liquor)

[1] None or less than once a month

[2] Once a month

[3] 2-3 times a month

[4] Once a week

[5] 2-3 times a week

[6] 4-6 times a week

[7] Once a day

[8] More than twice a day

C117. How many glasses of Soju do you drink at a time? (1 bottle $=6.5$ glasses, 1 glass $=50 \mathrm{cc}$ ) Answer__ glasses

C118. Beer

[1] None or less than once a month

[2] Once a month

[3] 2-3 times a month

[4] Once a week

[5] 2-3 times a week

[6] 4-6 times a week

[7] Once a day

[8] More than twice a day 
C119. How many glasses of beer do you drink at a time? (1bottle $=2.5$ mugs, 1 mug $=220 \mathrm{cc}$ ) glasses

Answer glasses

C120. M-akgeolli (rice wine)

[1] None or less than once a month

[2] Once a month

[3] 2-3 times a month

[4] Once a week

[5] 2-3 times a week

[6] 4-6 times a week

[7] Once a day

[8] More than twice a day

C121. How many glasses of Makgeolli do you drink at a time? (1bottle $=7$ glasses, 1 glass $=240 \mathrm{cc}$ ) glasses Answer glasses

C122. W-hisky and other liquors

[1] None or less than once a month

[2] Once a month

[3] 2-3 times a month

[4] Once a week

[5] 2-3 times a week

[6] 4-6 times a week

[7] Once a day

[8] More than twice a day

C123. How many glasses of whisky or liquor do you drink at a time? ( 1 bottle $=23$ glasses, 1 glass $=30 \mathrm{cc}$ ) glasses

Answer glasses

C124. Wine 
[1] None or less than once a month

[2] Once a month

[3] 2-3 times a month

[4] Once a week

[5] 2-3 times a week

[6] 4-6 times a week

[7] Once a day

[8] More than twice a day

C125. How many glasses of wine do you drink at a time? ( 1 bottle $=8$ glasses, 1 glass $=90 \mathrm{cc}$ ) glasses Answer glasses

WAVE 3 and WAVE 4

C122. Do you sometimes or often drink any alcoholic beverages, such as beer, wine, or liquor? 1. yes 2. No

C126. How often did you drink Soju (Korean liquor) in a month?

[1] None or less than once a month

[2] Once a month

[3] 2 3 times a month

[4] Once a week

[5] 2 3 times a week

[6] 4 6 times a week

[7] Once a day

[8] More than twice a day

C128. How often did you drink beer in a month?

C130. How often did you drink Makgeolli (rice wine) in a month?

C132. How often did you drink whisky and other liquors in a month

C134. How often did you drink wine in a month? 


\subsubsection{LASI}

HT214. Have you ever consumed any alcoholic beverages such as beer, wine, liquor, country liquor etc.?

1. Yes

2. No, never

HT215. [IF HT214=1] Do you currently drink any alcoholic beverages such as beer, wine, liquor, etc.?

1. Yes

2. No, I have quit drinking

HT216. [IF HT214=1 \& HT215=1] In the past 30 days, on the days that you drink, about how many drinks did you have?

number of drinks

HT217. [IF HT214=1 \& HT215=1] In the past 30 days, on average, how many days per week did you had any alcohol to drink? (For example, beer, wine, or any drink, such as country liquor, containing alcohol.) number of days per week

\subsubsection{CHARLS}

DA067. Did you drink any alcoholic beverages, such as beer, wine, or liquor in the past year? How often

(1) Drink more than once a month. 掲酒, 每月超过一次

(2) Drink but less than once a month 掲酒, 但每月少于一次

(3) None of these 什么都不掲

DA068. What type of alcoholic beverages did you drink? Liquor, wine, or beer ? (code all that apply)

(1).Liqor, including white liquor, whisky, and others 烈性酒，包括白酒、威士忌和其他酒

(2). Beer 啤酒

(3). Wine or rice wine 葡萄酒、米酒或黄酒 
DA069.Did you ever drink alcoholic beverages in the past? How often? 您以前掲酒吗？喝酒频率如何？

(1).I never had a drink.我从不或极少掲酒

(2).I used to drink less than once a month. 我很少喝酒，每月少于一次

(3).I used to drink more than once a month. 我以前喝酒，每月超过一次

Now, I am going to ask you how often and how much you drank during the past year. Please tell me how often you drank per month, and how much you drank at a time on average. I will repeat the questions for different types of alcoholic beverages. 现在我想了解过去一年您喝酒的情况。请回答您平均每个月喝多 少酒，一次大概掲多少。我会针对不同的酒类，分别提问。

DA072. How often did you drink liquor, including white liquor, whisky, and others per month in the last year ? 过去一年内您平均一个月喝几次烈性酒，包括白酒、威士忌？

(1) Once a month 每月一次

(2) 2-3 times a month 每月 2-3 次

(3) Once a week 每周一次

(4) 2-3 times a week 每周 2-3 次

(5) 4-6 times a week 每周 4-6 次

(6) Once a day 每天一次

(7) Twice a day 一天两次

(8) More than twice a day 一天超过两次

DA073. The last time you drank liquor last year, how many liang of liquor did you drink? (1 liang=50cc/50 ml) 请 问您过去一年内最近一次喝烈性酒，喝了多少两？（１两=50 毫升） liang 两

DA074. How many times per month did you drink beer in the last year ? 过去一年内您平均一个月喝几次 啤酒? 
(1) Once a month 每月一次

(2) 2-3 times a month 每月 2-3 次

(3) Once a week 每周一次

(4) 2-3 times a week 每周 2-3 次

(5) 4-6 times a week 每周 4-6 次

(6) Once a day 每天一次

(7) Twice a day 一天两次

(8) More than twice a day 一天超过两次

DA075. The last time you drank beer last year, how many bottles of beer did you drink? (1bottle=2.5 mugs,1mug=220cc) 请问您过去一年内最近一次喝啤酒，喝了多少瓶? ( 1 瓶=2.5 杯，1 杯=220 毫升 )

(DA075_1) 0..120bottles 瓶 or 或者（DA075_2)0..300mugs 杯

DA076. How often did you drink wine or rice wine per month in the last year ? 过去一年内您平均一个月喝 几次葡 萄酒、米酒或黄酒?

(1) Once a month 一个月一次

(2) 2-3 times a month 一个月 2-3 次

(3) Once a week 每周一次

(4) 2-3 times a week 每周 2-3 次

(5) 4-6 times a week 每周 4-6 次

(6) Once a day 每天一次

(7) Twice a day 一天两次

(8) More than twice a day 一天超过两次

DA077. The last time you drank it last year, how many liang of wine did you drink? (1 liang=50cc) 请问您过 去一年内最近一次喝葡萄酒、米酒或黄酒，喝了多少两？（1 两=50 毫升） liang 两

\subsubsection{JSTAR}

Tome27: In the past six months, about how frequently did you drink alcohol? 

1. Daily
2. 5-6 days per week
3. 3-4 days per week
4. 1-2 days per week
5. Several times per month
6. Hardly ever or never drink

Tom36: Please count the total you drank per day: Beer?

Tom37: Please count the total you drank per day: Shochu?

Tom38: Please count the total you drank per day: Sake?

Tom39: Please count the total you drank per day: Whiskey?

Tom40: Please count the total you drank per day: Wine?

Tom41: Please count the total you drank per day: Cocktails?

Tom42: Please count the total you drank per day: Other?

\subsubsection{TILDA}

None

\subsubsection{IFLS}

None

\subsubsection{MHAS}

C.60 Do you ever drink any alcoholic beverages such as beer, wine, liquor, or pulque?

C.61 In the last three months, about how many days a week have you had any alcohol to drink?

C.62 On the days you drank alcoholic beverages in the last three months, about how many drinks did you have per day?

NUMBER OF DRINKS ............. $\left.\right|_{\ldots}{ }_{\ldots}$

C.63 In the last three months, on how many days have you had four or more drinks on one occasion? NUMBER OF DAYS

C.64 Have you ever had an alcoholic drink in your life? 
YES

NO 2

RF 8

DK.

\subsection{Physical activity}

\subsubsection{HRS}

LC223 HOW OFTEN VIGOROUS ACTIVITY

We would like to know the type and amount of physical activity involved in your daily life. How often do you take part in sports or activities that are vigorous, such as running or jogging, swimming, cycling, aerobics or gym workout, tennis, or digging with a spade or shovel: more than once a week, once a week, one to three times a month, or hardly ever or never?

1. MORE THAN ONCE A WEEK

2. ONCE A WEEK

3. ONE TO THREE TIMES A MONTH

4. HARDLY EVER OR NEVER

7. (VOL) EVERY DAY

\section{LC224 HOW OFTEN MODERATE ACTIVITY}

And how often do you take part in sports or activities that are moderately energetic such as, gardening, cleaning the car, walking at a moderate pace, dancing, floor or stretching exercises: (more than once a week, once a week, one to three times a month, or hardly ever or never)?

1. MORE THAN ONCE A WEEK

2. ONCE A WEEK

3. ONE TO THREE TIMES A MONTH

4. HARDLY EVER OR NEVER

7. (VOL) EVERY DAY

\section{LC225 HOW OFTEN MILD ACTIVITY}

And how often do you take part in sports or activities that are mildly energetic, such as vacuuming, laundry, home repairs: (more than once a week, once a week, one to three times a month, or hardly ever or never)?

1. MORE THAN ONCE A WEEK 
2. ONCE A WEEK

3. ONE TO THREE TIMES A MONTH

4. HARDLY EVER OR NEVER

7. (VOL) EVERY DAY

\subsubsection{ELSA}

HeActa

SHOW CARD O

We would like to know the type and amount of physical activity involved in your daily life. Do you take part in sports or activities that are vigorous ...READ OUT...

1 more than once a week,

2 once a week,

3 one to three times a month,

4 hardly ever, or never?

HeActb

SHOW CARD O

And do you take part in sports or activities that are moderately energetic ...READ OUT...

1 more than once a week,

2 once a week,

3 one to three times a month,

4 hardly ever, or never?

HeActc

SHOW CARD O

And do you take part in sports or activities that are mildly energetic ...READ OUT...

1 more than once a week,

2 once a week,

3 one to three times a month,

4 hardly ever, or never? 


\subsubsection{SHARE}

\section{BR015_SPORTS OR ACTIVITIES THAT ARE VIGOROUS}

We would like to know about the type and amount of physical activity you do in your daily life. How often do you engage in vigorous physical activity, such as sports, heavy housework, or a job that involves physical labor?

IWER: READ OUT

1. More than once a week

2. Once a week

3. One to three times a month

4. Hardly ever, or never

\section{BR016_ACTIVITIES REQUIRING A MODERATE LEVEL OF ENERGY}

How often do you engage in activities that require a low or moderate level of energy such as gardening, cleaning the car, or doing a walk? IWER: READ OUT

1. More than once a week

2. Once a week

3. One to three times a month

4. Hardly ever, or never

\subsubsection{Klosa}

c096. The next few questions are about exercise. Do you work out more than once a week?

[1]. Yes

[5]. No

C098. How often do you work out per week?

Answer range (1-97)

C099. For how long do you work out per session?

Answer minutes range (1-168)

C100. How long have you been working out regularly?

[1] Less than 3 months 
[2] 4-6 months

[3] 7 months-1 year

[4] 1-2 years

[5] 3-4 years

[6] 5-6 years

[7] More than 7 years

\subsubsection{LASI}

HT218. We would like to know the type and amount of physical activity involved in your daily life. How often do you take part in sports or activities that are vigorous, such as running or jogging, swimming, going to a health center or gym, cycling, or digging with a spade or shovel, heavy lifting, chopping, farm work, fast bicycling, cycling with loads: everyday, more than once a week, once a week, one to three times a month, or hardly ever or never?

1. Everyday

2. More than once a week

3. Once a week

4. One to three times a month

5. Hardly ever or never

HT220. [If R says $1,2,3$, or 4 to HT218] Now, think about all the vigorous physical activities that you did in the past 7 days. Did you do any vigorous activity for at least 20 minutes continuously?

1. Yes

2. No

HT221. [If R says Yes to HT220, ask] During the past 7 days, on how many days did you do vigorous activity for at least 20 minutes?

days

HT222_intro. [If R says Yes to HT220, ask] One the days you did vigorous activity, how much time did you usually spend doing any vigorous activity?

HOURS__ OR MINUTES 
HT219. And how often do you take part in sports or activities that are moderately energetic such as, cleaning house, washing clothes by hand, fetching water or wood, drawing water from a well, gardening, bicycling at a regular pace, walking at a moderate pace, dancing, floor or stretching exercises: (everyday, more than once a week, once a week, one to three times a month, hardly ever, or never)?

1. Everyday

2. More than once a week

3. Once a week

4. One to three times a month

5. Hardly ever or never

HT223. [If R says 1, 2, 3, or 4 to HT219, ask] Now, think about all the moderate physical activities that you did in the past 7 days. Did you do any moderate activity for at least 20 minutes continuously?

1. Yes

2. No

HT224. [If R says Yes to HT223, ask] During the past 7 days, on how many days did you do moderate activity for at least 20 minutes?

days

HT225_intro. [If R says Yes to HT223, ask] How much time did you usually spend doing any moderate activity on an average in a day?

HOURS__ OR MINUTES

\subsubsection{CHARLS}

Now we would like to ask about the amount of time you spend on different types of physical activities in a usual week.

Now, think about all the vigorous activities requiring hard/high-intensity physical effort that you do in a usual week. Vigorous activities make you breathe much harder than normal and may include heavy lifting, 
digging, plowing, aerobics, fast bicycling, and cycling with a heavy load. Think only about those physical activities that you did for at least 10 minutes at a time.

DA051_1_

During a usual week, did you do any vigorous activities for at least 10 minutes continuously?

1.Yes

2. No

DA052_1_

During a usual week, on how many days did you do vigorous activities at least 10 minutes? days (1-7)

\section{DA053_1_}

How much time did you usually spend doing vigorous activities on one of those days?

1. $<2$ hours - go to DA054

2. $>=2$ hours - go to DA055

\section{DA054_1_}

1. $<30$ minutes

2. $>=30$ minutes

\section{DA055_1_}

1. $<4$ hours

2. $>=4$ hours

Now, think about activities which take moderate physical effort that you do in a usual week. Moderate physical activities make you breathe somewhat harder than normal and may include carrying light loads, bicycling at a regular pace, or mopping the floor. Again, think about those physical activities that you did for at least 10 minutes at a time.

DA051_2_

During a usual week, did you do any vigorous activities for at least 10 minutes continuously? 
1.Yes

2. No

DA052_2

During a usual week, on how many days did you do vigorous activities at least 10 minutes? days (1-7)

DA053_2

How much time did you usually spend doing vigorous activities on one of those days?

$1<2$ hours - go to DA054

$2>=2$ hours - go to DA055

DA054_2

$1<30$ minutes

$2>=30$ minutes

DA055_2_

$1<4$ hours

$2>=4$ hours

Now, think about the time you spend walking in a usual week. This includes at work and at home, walking to travel from place to place, and any other walking that you might do solely for recreation, sport, exercise or leisure.

DA051_3_

During a usual week, did you do any vigorous activities for at least 10 minutes continuously?

1.Yes

2. No

DA052_3_

During a usual week, on how many days did you do vigorous activities at least 10 minutes? days (1-7) 
DA053_3_

How much time did you usually spend doing vigorous activities on one of those days?

$1<2$ hours - go to DA054

$2>=2$ hours - go to DA055

DA054_3_

$1<30$ minutes

$2>=30$ minutes

\section{DA055_3}

$1<4$ hours

$2>=4$ hours

\subsubsection{JSTAR}

Tome151

How much time do you do exercise, sports, walking during the weekdays? (mins)

Tome165

How much time do you do exercise, sports, walking during the weekend? (mins

\subsubsection{TILDA}

BH101: During the last 7 days, on how many days did you do vigorous physical activities like heavy lifting, digging, aerobics, or fast bicycling?

1. N__ Number of days per week

5. No I have not done any vigorous physical activities GO TO BH103

BH102: How much time did you usually spend doing vigorous physical activities on one of those days? hours per day $(0 \ldots 10)$ minutes per day [bh102a] 
BH103: Think about all the moderate activities that you did in the last 7 days. Moderate activities refer to activities that take moderate physical effort and make you breathe somewhat harder than normal. Think only about those physical activities that you did for at least 10 minutes at a time. During the last 7 days, on how many days did you do moderate physical activities like carrying light loads, bicycling at a regular pace, or doubles tennis? Do not include walking.

1. days per week

5. No I have not done any moderate physical activities GO TO BH105

BH104: How much time did you usually spend doing moderate physical activities on one of those days? hours per day $(0 \ldots 10)$ minutes per day [bh104a]

BH105: Now think about the time you spent walking in the last 7 days. This includes at work and at home, walking to travel from place to place, and any other walking that you might do solely for recreation, sport, exercise, or leisure.

During the last 7 days, on how many days did you walk for at least 10 minutes at a time?

1. days per week

5. No I have not done any walking GO TO BH107

BH106: How much time did you usually spend walking on one of those days? hours per day $(0 \ldots 5)$ minutes per day [bh106a]

BH107: The last question is about the time you spent sitting on weekdays during the last 7 days. Include time spent at work, at home, while doing course work and during leisure time. This may include time spent sitting at a desk, visiting friends, reading, or sitting or lying down to watch television. During the last 7 days, how much time (per day) did you spend sitting on a week day?

(This question is looking for the usual number of hours spent sitting on a typical week day. If respondent has difficulty calculating, interviewer may suggest they approximate by subtracting time spent sleeping, walking, standing, exercising etc. from the 24 hours) 
hours per day $(0 \ldots 20)$

minutes per day [bh107a]

\subsubsection{IFLS}

KKO2m_A

During the last 7 days, did you do any vigorous activities for at least 10 minutes continuously?

1.Yes

3. No

KKO2n_A

How much time did you usually spend doing vigorous activities on one of those days?

1. $<2$ hours

2. $\geq 2$ hours

11. $<30$ minutes

12. $\geq 30$ minutes

21. $<4$ hours

22. $\geq 4$ hours

KK02O_A

During the last 7 days, on how many days did you do vigorous activities?

$\llcorner$ days

B. Now think about activities which take moderate physical effort that you did in the last 7 days. Moderate physical activities make you breathe somewhat harder than normal and may include carrying light loads, bicycling at a regular pace, or mopping the floor. Again, think about only those physical activities that you did for at least 10 minutes at a time.

KKO2m_B

During the last 7 days, did you do any moderate activities for at least 10 minutes continuously?

1.Yes

3. No 
KKO2n_B

How much time did you usually spend doing moderate activities on one of those days?

1. $<2$ hours

2. $\geq 2$ hours

11. $<30$ minutes

12. $\geq 30$ minutes

21. $<4$ hours

22. $\geq 4$ hours

KKO2O_B

During the last 7 days, on how many days did you do moderate activities?

$\llcorner$ days

C. Now think about the time you spent walking in the last 7 days. This includes at work and at home, walking to travel from place to place, and any other walking that you might do solely for recreation, sport, exercise, or leisure.

KKO2m_C

During the last 7 days, did you do any walking activities for at least 10 minutes continuously?

1.Yes

3. No

KKO2n_C

How much time did you usually spend doing walking activities on one of those days?

1. $<2$ hours

2. $\geq 2$ hours

11. $<30$ minutes

12. $\geq 30$ minutes

21. $<4$ hours

22. $\geq 4$ hours

KK02o_C 
During the last 7 days, on how many days did you do walking activities?

$\llcorner$ days

D. Now think about the time you spent sitting on week days during the last 7 days. Include time spent at work, at home, while doing course work, and during leisure time. This may include time spent sitting at a desk, visiting friends, reading or sitting or lying down to watch television.

KKO2m_D

During the last 7 days, did you do any sitting activities for at least 10 minutes continuously?

1.Yes

3. No

KKO2n_D

How much time did you usually spend doing sitting activities on one of those days?

1. $<2$ hours

2. $\geq 2$ hours

11. $<30$ minutes

12. $\geq 30$ minutes

21. $<4$ hours

22. $\geq 4$ hours

KKO2O_D

During the last 7 days, on how many days did you do sitting activities?

$\downarrow$ days

\subsubsection{MHAS}

C.53

On average during the last two years, have you exercised or done hard physical work three or more times a week? Including various activities such as sports, heavy household chores, or other physical work.

1.Yes

2.No 
Table 9. Question Numbers in Each Survey

\begin{tabular}{|c|c|c|c|c|c|c|c|c|c|c|c|c|c|c|}
\hline \multirow{2}{*}{$\begin{array}{l}\text { Health } \\
\text { Behaviors }\end{array}$} & \multirow[t]{2}{*}{ HRS } & \multicolumn{3}{|c|}{ ELSA } & \multicolumn{2}{|c|}{ SHARE } & \multicolumn{2}{|c|}{ KLoSA } & \multirow[t]{2}{*}{ LASI } & \multirow[t]{2}{*}{ CHARLS } & \multirow[t]{2}{*}{ JSTAR } & \multirow[t]{2}{*}{ TILDA } & \multirow[t]{2}{*}{ IFLS } & \multirow[t]{2}{*}{ MHAS } \\
\hline & & W1 & W2 W3 & W4 W5 & W1 & $\begin{array}{l}\text { W2 } \\
\text { W4 }\end{array}$ & W1 & $\begin{array}{l}\text { W2 w3 } \\
\text { w4 }\end{array}$ & & & & & & \\
\hline Ever Smoke & LC116 & HeSmk & HeSmk & HeSmk & BR001 & BR001 & C103 & C116 & HT205 & DA059 & Tome21 & $\mathrm{BH} 001$ & KM01a & C54 \\
\hline Smoke Now & LC117 & HESka & HESka & HESka & BR002 & BR002 & C104 & C117 & HT206 & DA061 & Tome21 & $\mathrm{BH} 002$ & KMO4 & C55 \\
\hline $\begin{array}{l}\text { \# cigarettes } \\
\text { smoked }\end{array}$ & $\begin{array}{l}\text { LC118, } \\
\text { LC119 }\end{array}$ & $\begin{array}{l}\text { HeSKkc, } \\
\text { HeTba, } \\
\text { HeTbc }\end{array}$ & $\begin{array}{l}\text { HeSKkc } \\
\text { HeTba } \\
\text { HeTbc }\end{array}$ & $\begin{array}{l}\text { HeSKkc } \\
\text { HeTba } \\
\text { HeTbc }\end{array}$ & $\begin{array}{l}\text { BR006 } \\
\text { BR007 } \\
\text { BR008 }\end{array}$ & $\begin{array}{l}\text { BR006 } \\
\text { BR007 } \\
\text { BR008 }\end{array}$ & C105 & C119 & $\begin{array}{l}\text { HT207 } \\
\text { HT207b } \\
\text { HT208 }\end{array}$ & DA063 & $\begin{array}{l}\text { Tome23 } \\
\text { Tome24 } \\
\text { Tome25 }\end{array}$ & $\begin{array}{l}\text { BH006 } \\
\text { BH007 } \\
\text { BH008 }\end{array}$ & $\begin{array}{l}\text { KM06, } \\
\text { KM08 }\end{array}$ & C56 \\
\hline $\begin{array}{l}\text { When } \\
\text { smoking } \\
\text { most, how } \\
\text { much }\end{array}$ & LC123 & & & & & & C107 & C120 & & & & & & C58 \\
\hline Age started & LC120 & & & & BR003 & BR003 & C108 & C118 & HT211 & DA065 & Tome22 & & KM10 & C57 \\
\hline $\begin{array}{l}\text { Age } \\
\text { stopped }\end{array}$ & & & & & BR004 & & C106 & C121 & HT213 & DA062 & Tome26 & $\mathrm{BH} 003$ & KM05aa & \\
\hline type & & HECig & HECig & HECig & BR005 & BR005 & & & & DA060 & & $\mathrm{BH} 005$ & $\begin{array}{l}\text { KM01b } \\
\text { KM01c } \\
\text { KM01d } \\
\text { KM01e }\end{array}$ & \\
\hline $\begin{array}{l}\text { Ever } \\
\text { Drinking }\end{array}$ & LC128 & HeA1a & SCAKO & SCAKO & BR010_ & BR010_ & C109 & C122 & HT214 & DA069 & Tome27 & & & C60 \\
\hline $\begin{array}{l}\text { \#days/week } \\
\text { drinks }\end{array}$ & LC129 & & SCAL7B & SCAL7B & BR010_ & BR010_ & $\begin{array}{l}\text { C116 } \\
\text { C118 } \\
\text { C120 } \\
\text { C122 } \\
\text { C124 }\end{array}$ & $\begin{array}{l}\text { C126 C128 } \\
\text { C130 C132 } \\
\text { C134 }\end{array}$ & & $\begin{array}{l}\text { DA074 } \\
\text { DA076 }\end{array}$ & & & & $\mathrm{C} 63$ \\
\hline $\begin{array}{l}\text { \#drinks/day } \\
\text { when } \\
\text { drinks }\end{array}$ & LC130 & & $\begin{array}{l}\text { SCABNP } \\
\text { SCABNLC } \\
\text { SCABSP } \\
\text { SCABSLC } \\
\text { SCABNSC } \\
\text { SCASPIR } \\
\text { SCASHER } \\
\text { SCAWIN } \\
\text { SCAPOPG }\end{array}$ & $\begin{array}{l}\text { SCDRSPI } \\
\text { SCDRWIN } \\
\text { SCDRPIN }\end{array}$ & & BR019_ & $\begin{array}{l}\text { C117 } \\
\text { C119 } \\
\text { C121 } \\
\text { C123 } \\
\text { C125 }\end{array}$ & $\begin{array}{l}\text { C127 C129 } \\
\text { C131 C133 } \\
\text { C135 }\end{array}$ & HT216 & $\begin{array}{l}\text { DA073 } \\
\text { DA075 } \\
\text { DA077 }\end{array}$ & $\begin{array}{l}\text { Tome36 } \\
\text { Tome37 } \\
\text { Tome38 } \\
\text { Tome39 } \\
\text { Tome40 } \\
\text { Tome41 } \\
\text { Tome42 }\end{array}$ & & & C62 \\
\hline $\begin{array}{l}\text { Type of } \\
\text { drink }\end{array}$ & & & SCDRI & & & & & & & DA068 & & & & \\
\hline $\begin{array}{l}\text { Vigorous } \\
\text { physical } \\
\text { activity }\end{array}$ & LC223 & HeActa & HeActa & HeActa & Br015_ & Br015_ & & & HT218 & $\begin{array}{l}\text { DA051_1 } \\
\text { DA052_1 } \\
\text { DA053_1 }\end{array}$ & & BH101 & KK02m_A & C53 \\
\hline $\begin{array}{l}\text { Moderate } \\
\text { physical } \\
\text { activity }\end{array}$ & LC224 & Heactb & Heactb & Heactb & Br016_ & Br016_ & & & $\mathrm{Ht} 219$ & $\begin{array}{l}\text { DA051_2 } \\
\text { DA052_2 } \\
\text { DA053_2 }\end{array}$ & & $\mathrm{BH} 103$ & KKO2m_B & \\
\hline $\begin{array}{l}\text { Light } \\
\text { physical } \\
\text { activity }\end{array}$ & LC225 & HeActc & HeActc & HeActc & & & & & & $\begin{array}{l}\text { DA051_3 } \\
\text { DA052_3 } \\
\text { DA053_3 }\end{array}$ & & BH105 & KKO2m_C & \\
\hline
\end{tabular}

